\title{
Rodent Models of Amyloid-Beta Feature of Alzheimer's Disease: Development and Potential Treatment Implications
}

\author{
Chi Him Poon",\#, Yingyi Wang,"\#, Man-Lung Fung'1, Chengfei Zhang², Lee Wei Lim ${ }^{1 *}$ \\ ${ }^{1}$ School of Biomedical Sciences, Li Ka Shing Faculty of Medicine, The University of Hong Kong, Hong Kong, \\ China. \\ ${ }^{2}$ Endodontology, Faculty of Dentistry, The University of Hong Kong, Hong Kong, China
}

[Received September 19, 2019; Revised October 24, 2019; Accepted October 26, 2019]

\begin{abstract}
Alzheimer's disease (AD) is the most common neurodegenerative disorder worldwide and causes severe financial and social burdens. Despite much research on the pathogenesis of AD, the neuropathological mechanisms remain obscure and current treatments have proven ineffective. In the past decades, transgenic rodent models have been used to try to unravel this disease, which is crucial for early diagnosis and the assessment of disease-modifying compounds. In this review, we focus on transgenic rodent models used to study amyloidbeta pathology in AD. We also discuss their possible use as promising tools for AD research. There is still no effective treatment for AD and the development of potent therapeutics are urgently needed. Many molecular pathways are susceptible to $\mathrm{AD}$, ranging from neuroinflammation, immune response, and neuroplasticity to neurotrophic factors. Studying these pathways may shed light on AD pathophysiology as well as provide potential targets for the development of more effective treatments. This review discusses the advantages and limitations of these models and their potential therapeutic implications for AD.
\end{abstract}

Key words: Alzheimer's disease, amyloid-beta, neuroinflammation, neuroplasticity, neurotrophic factors.

\section{Introduction}

Alzheimer's disease (AD) has a high incidence rate affecting nearly 40 million people worldwide, which is predicted to increase in the coming years [1]. It is one of the most common causes of senile dementia in Europe and America, and is estimated to account for $50 \%-80 \%$ of all senile dementia cases worldwide [2]. In 2015, AD resulted in 110,561 deaths in Americans above 65 years of age, which was the sixth leading cause of death in the United States. In 2017, more than 16 million family caregivers provided an estimated 18.4 billion hours of care to patients with Alzheimer's and other dementias at an estimated cost of over $\$ 232$ billion, not to mention the intangible cost of the physical and psychological stress experienced by these carers [3]. Symptoms of AD include progressive cognitive decline, which is characterized by initial memory loss that gradually progresses to cognitive impairments and behavioral changes. Generally, AD patients do not present with clinical symptoms until the dementia stage, which makes early diagnosis difficult and makes the clinical study of AD pathogenesis challenging.

During the past 20 years, the identification of genes and proteins related to $\mathrm{AD}$ has led to the development of transgenic rodent models. These rodent models play an important role in the elucidation of the underlying disease

*Correspondence should be addressed to: Dr. Lee Wei Lim, School of Biomedical Sciences, Li Ka Shing Faculty of Medicine, The University of Hong Kong, Hong Kong, China. Email: drlimleewei@ gmail.com. \#These authors contributed equally to this work.

Copyright: (C) 2019 Poon $\mathrm{CH}$ et al. This is an open-access article distributed under the terms of the Creative Commons Attribution License, which permits unrestricted use, distribution, and reproduction in any medium, provided the original author and source are credited. 
mechanisms of $\mathrm{AD}$, and significant progress has been made in understanding the neurobiological basis of $\mathrm{AD}$. These transgenic rodent models are also useful for testing the effects of potential therapeutic novel drugs and interventions. However, the heterogeneous nature of $\mathrm{AD}$ hinders the development of effective therapeutics. It is well known that the main neuropathological hallmarks of $\mathrm{AD}$ include amyloid plaques and neurofibrillary tangles, as well as the loss of certain neurons, especially cholinergic, noradrenergic, serotonergic, and pyramidal neurons [4]. Amyloid plaques are composed of dystrophic neurites surrounded by a central core, whereas neurofibrillary tangles are composed of highly phosphorylated microtubule-associated tau proteins in specific neuronal perikarya. In the past decades, a deeper understanding of neurobiological basis of the etiology and pathogenesis $\mathrm{AD}$ involving neuroprotection, neuroplasticity, and anti-neuroinflammation pathways has led to the rapid development of potential treatments based on these pathways.

Neuron loss can occur in the early stage of AD even before senile plaques and neurofibrillary tangles have developed [5]. Loss of neurons is regarded as one of the causes of brain function decline. Compared to normal aging, neuron death in $\mathrm{AD}$ was observed to be more intense in certain brain areas $[6,7]$. In the early stage of $\mathrm{AD}$, the neuron loss starts in hippocampal area CA1, dentate fascia, subiculum, and layer 2 of entorhinal cortex $[5,8-10]$, which then spreads into the temporal, frontal, and parietal lobes of the cerebral cortex [6]. In the late stage of $\mathrm{AD}$, neuron loss is observed in the whole brain including olfactory bulbs [11], amygdala, basal nucleus of Meynert [12, 13], substantia nigra [14], locus coeruleus [15], and dorsal raphe nucleus [16]. Decreased neuron numbers in the CA1 and entorhinal cortex was associated with memory impairment [17]. The decline in the number of neurons is caused by the disruption of normal physiological processes including postnatal neurogenesis and natural neuronal death. These alterations could also result from suppressed maturation and functional integration of new born neurons in the dentate gyrus [18], as well as reduced postnatal neurogenesis occurring in the subventricular area and dentate gyrus $[19,20]$. However, the exact molecular mechanism that induces neuron loss in $\mathrm{AD}$ has not yet been established.

Neurofibrillary tangles are considered to be one of the major pathological features of $\mathrm{AD}$ and the main microscopic lesion. These abnormal fibrous inclusions were first discovered in 1907 by Alois Alzheimer in perikaryal cytoplasm of pyramidal neurons [21]. The neurofibrillary tangle has been widely studied in the past decades. On a ultrastructural level, the neurofibrillary tangle consists of abnormal fibrils approximately $10 \mathrm{~nm}$ in diameter, which appear as helically wound pairs of filaments with a periodicity of $80 \mathrm{~nm}[22,23]$. The main component of the neurofibrillary tangle is hyperphosphorylated microtubule-associated Tau protein, which is located on specific molecular sites in the neurofibrillary tangles [24]. Although the neurofibrillary tangles contain many other proteins including cholinesterases [25], ubiquitin [26, 27], and beta-amyloid 4 [28], Tau is regarded as the most important component. In clinical cases of $\mathrm{AD}$, neurofibrillary tangles were generally found in most brain areas and its distribution mode is relatively predictable. Severe neurofibrillary tangles were observed in the layer 2 neurons of the entorhinal cortex, CA1 and subiculum regions of the hippocampus, amygdala, and deeper layers (layers III, V, and superficial VI) of the neocortex in AD brain [29]. The range and location of neurofibrillary tangles in $\mathrm{AD}$ patients are associated with the degree of dementia and the stage of disease [30,31], indicating these pathological features may be involved in the disruption of brain function.

Senile or neuritic plaques are also considered to be a main pathological feature of AD. Senile plaques are a common pathologic feature found in post-mortem AD patients [32] and $\mathrm{AD}$ animal models [33]. Several forms of amyloid-beta $(A \beta)$ plaques are also observed in aged people as well as in AD patients. The main component of these plaques is beta-amyloid A4 ( $\beta \mathrm{A} 4)$ protein located in the central core, which displays a radial arrangement and is surrounded by abnormally generated neurites or neuronal processes [34]. It is more common to find neuritic plaques surrounded by several microglial cells, instead of reactive astrocytes [34]. Currently, there are ongoing debates regarding the involvement of microglia in the neuroinflammatory pathogenetic cascade and in the reaction to components within lesions [35]. The $\beta A 4$ protein is generated from a larger transmembrane glycoprotein called amyloid precursor protein (APP) [36]. Two secretases split the amino and carboxyl terminals of the 4-kD segment to generate the $\beta A 4$ fragment [37-39]. Interestingly, due to irregular cleavage of the carboxyl end, this process can generate products with different lengths. Depending on the lengths, these products can either accumulate within senile plaque (42 or 43 amino acids) or deposit within the leptomeningeal, cerebral cortical, and cerebellar blood vessels (40 amino acids) [40].

\section{Amyloid-beta pathology in mouse models}

Based on the current evidence, $A \beta$ is a significant pathological factor with many established associations with other pathologies present in AD. In 1992, Hardy and Higgins [41] first proposed the amyloid cascade hypothesis, which has been gradually modified in the past 
two decades. The amyloid cascade hypothesis is considered to be one of the dominant theories in AD and has gained much support [42]. This hypothesis is important for $\mathrm{AD}$ research as it postulates that $\mathrm{A} \beta$ facilitates the progression of $\mathrm{AD}$ and leads to other downstream phenotypic manifestations such as cognitive declines and Tau pathology. Furthermore, in-vitro and transgenic animal model experiments showed that intraneuronal accumulation of $\mathrm{A} \beta$ precedes the pathological manifestations of $\mathrm{AD}$ and contributes to various pathological effects on cellular functions [43].

Given the importance of $\mathrm{A} \beta$ in $\mathrm{AD}$ pathogenesis, this review focuses on the use of transgenic rodent models to study beta-amyloid in AD pathogenesis. Transgenic rodent models of $A \beta$ accumulation or amyloid plaque formation can mimic many aspects of human AD and have provided much evidence to support the amyloid cascade hypothesis. These rodent models are, therefore, invaluable as tools for exploring the pathological processes in $\mathrm{AD}$ and the relationship between $\mathrm{AD}$ pathology and the cerebral microenvironment.

With the identification of genes associated with $\mathrm{AD}$ progression such as amyloid precursor protein, presenilin 1 (PS1), and presenilin 2 (PS2), several mouse models based on these mutations have since been generated [44]. These transgenic rodent models have been important tools for clarifying the underlying mechanisms of $\mathrm{AD}$ and to explore biomarkers of the early stage AD. Unlike humans, rodents do not develop $\mathrm{A} \beta$ plaques in the natural aging process, which could be due to differences in the three $A \beta$ sequences across species [45]. Several mouse models have been generated with genetic mutations related to human amyloid precursor protein (APP), C-terminal fragment of APP [46], A $\beta$, and familial forms of Alzheimer's disease [47-50], which result in robust $\mathrm{A} \beta$ accumulation.

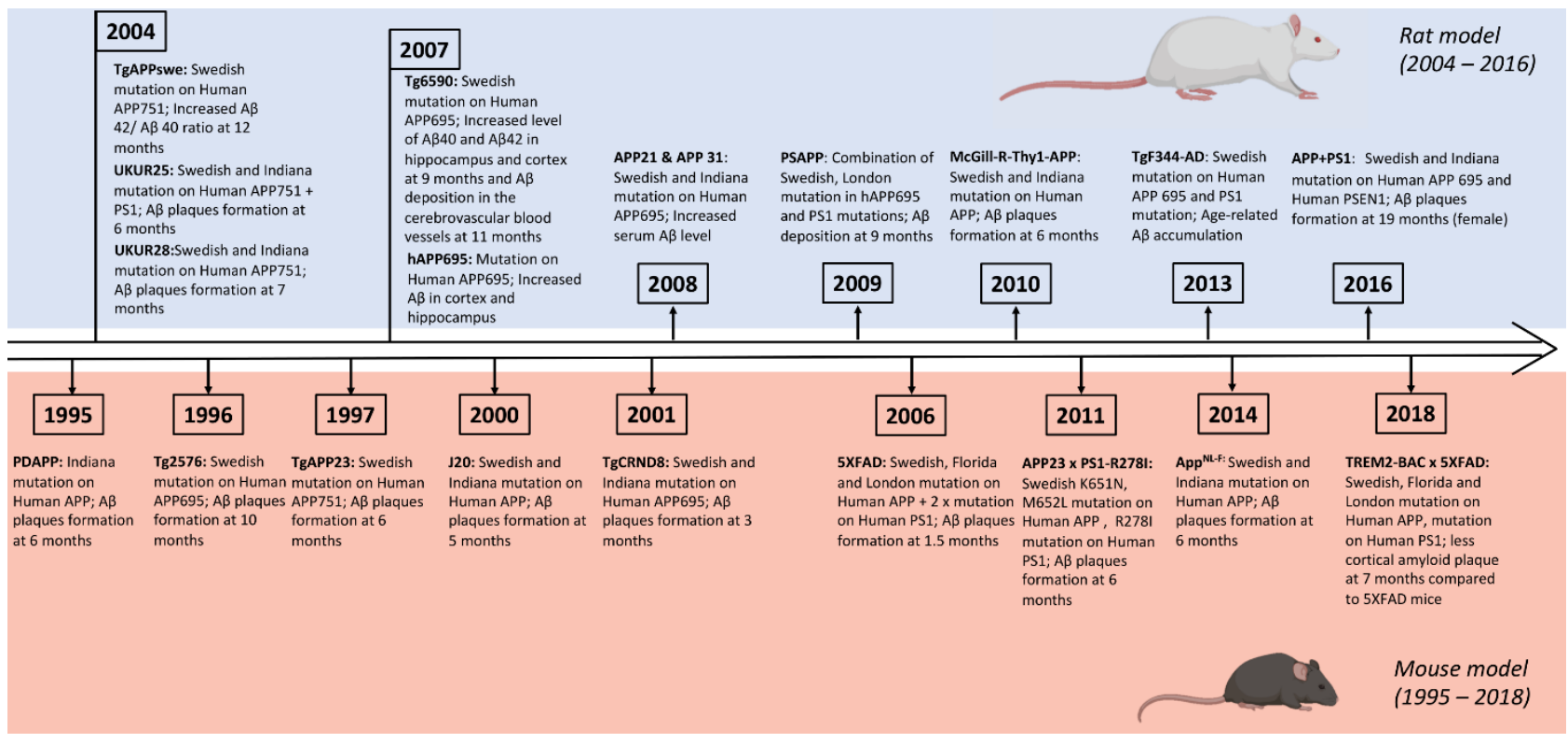

Figure 1. Timeline illustrating the development of transgenic mouse and rat models of AD.

\section{Transgenic mouse models with human APP mutation}

The most common approach to generate transgenic AD mouse models is to overexpress the Familial Alzheimer's disease (FAD)-related human APP mutation. This transgenic $\mathrm{AD}$ mouse model exhibits rapid disease manifestation and plaque formation and has been widely used in many research studies. Nowadays, more than 50 transgenic mouse models are used in this field of research, and the majority of them are characterized by the overexpression of human wildtype or FAD-related mutant APP.

The first mouse models were generated by overexpressing human wildtype APP. However, these mice had only mild neuropathological manifestations and did not exhibit $\mathrm{A} \beta$ plaques, indicating a failure to effectively mimic human AD [51-53]. Subsequently, mouse models generated with FAD-related APP mutations gradually developed the molecular pathology. Mice with these APP mutations manifested an age-related increase and maturation of amyloid plaques in the brain. The 
minimum age of the formation of amyloid plaques in mutant mice was found to be closely associated with the chosen mutations and transgenic expression promoters that govern the transcript level of transgenes in the brain. Notably, the majority of transgenic mice models expressing mutant human APP showed an age-dependent cognitive decline resembling that of human AD [54-56]. These mutant mice also displayed some neuropathological features of human $\mathrm{AD}$, such as dystrophic neurites, reactive astrocytes, activated microglia, increased innate immunity and inflammation, synapse loss, and disrupted electrophysiological and neurochemical signaling [57]. However, only a few of these transgenic mice exhibited significant neural degeneration or neurofibrillary tangle (NFT)-like tau [57], suggesting overexpression of FAD-related APP mutations is not sufficient to completely mimic human AD.

A common mutation in transgenic $A D$ mice is Swedish double APP mutation, with about half of the APP transgenic mice models overexpressing this mutation. A widely used model is the Tg2576 mouse model, which possesses the Swedish mutation driven by the hamster prion promoter that leads to transgene expression in the forebrain area and spinal cord [58]. These mice have thioflavin-S-positive $A \beta$ plaques at the age of 10-12 months, and also generate oligomeric $\mathrm{A} \beta$, a toxic component of the plaque [59]. Although Tg2576 mice did not show significant neuronal loss in brain areas [60], they did have impaired dendritic spine stability, leading to severe spine loss and reduced synaptic plasticity [61]. Nevertheless, it is not known whether synaptic loss or cognitive declines are consequences of the formation of $\mathrm{A} \beta$ oligomers, fibrils, or plaques.

Another APP transgenic mouse model, TgAPP23, was generated using a longer 751 amino acid version of APP with the expression driven by promoter murine Thy1.2. This mouse model exhibited amyloid deposition at the age of 6 months, with the severity escalating by 12 months particularly in brain vessels, leading to gradually reduced blood flow and altered vessel morphology [62, 63]. These mice also showed reactive gliosis, astrocytosis, dystrophic neurites, synaptic loss, and even neuron loss in the hippocampal area CA1 at 14-18 months [64].

The PDAPP mouse model expressing a human Indiana mutation of APP minigene was driven by the promoter of platelet-derived growth factor [54, 65]. Compared to other mouse models, PDAPP mice had agedependent diffuse and dense $A \beta$ plaques at the age of 6-9 months. These mice also showed reactive astrocytes around these $A \beta$ plaques and significant synaptic loss with age, but no evidence of neuronal loss in AD pathologyrelated brain areas such as entorhinal cortex and hippocampal area CA1 $[54,66]$.
Taken together, these findings suggest the progress of $\mathrm{A} \beta$ pathology in these mice is largely dependent on the expression of the transgene and formation of specific $A \beta$ species in the brain. Thus, another strategy to facilitate $A \beta$ pathology is to combine several FAD-related mutations. Generally, the combination of Swedish double mutations and APP transgene mutations accelerated the generation of toxic $\mathrm{A} \beta 42$ peptides, resulting in a more rapid and robust presentation of $\mathrm{A} \beta$ pathology compared to the above transgenic mouse models. For instance, J20, APP22, and TgCRND8 mouse models with several FADrelated mutations exhibited more robust $\mathrm{A} \beta$ pathology $[53,56,67]$. The J20 mice displayed diffuse amyloid deposits in the hippocampus and neocortex at the age of 5-6 months and subsequently showed large neuritic plaques by 9 months [68]. These mice also showed a decline in synaptophysin immunoreactivity, suggesting altered synaptic function [69]. The J20 mice exhibited significant deficits in spatial learning and memory, suggesting these molecular pathologies may translate to cognitive impairments [70]. Another mouse model, TgCRND8, with multiple FAD-related mutations showed even earlier onset of pathologies, with significant cognitive impairment and $A \beta$ plaque deposition at 3 months [67], and activation of immune or inflammatory reaction and cholinergic input loss at 7 months [71]. These findings indicate that multiple transgenes can contribute to an accelerated $\mathrm{A} \beta$ pathology.

The current evidence derived from APP transgenic mice and clinical research indicates that $A \beta$ oligomers, instead of plaques, may lead to the clinical phenotypes observed [72]. A new APP transgenic mouse, $\mathrm{APP}_{\mathrm{E} 693} \Delta-$ $\mathrm{Tg}$, provided further evidence that $\mathrm{A} \beta$ oligomers play an important role in AD pathology and cognitive deficits. This mouse model did not display any extracellular $A \beta$ plaques, but had increased accumulation of soluble $A \beta$ oligomers in neurons [73]. At the age of 8 months, they exhibited synaptic loss and increased phospho-tau in mossy fibers, which are associated with the accumulation of $A \beta$ oligomers [57]. At an older age of 18-24 months, they exhibited gliosis and neuronal loss in hippocampal area $C A 3$ [57]. These results support the notion that $A \beta$ oligomers, instead of plaques, may be a crucial component that triggers neurotoxicity and cognitive impairment in $\mathrm{AD}$. This phenomenon resembles the observations from clinical studies in $\mathrm{AD}$ patients that showed a link between cerebral $A \beta$ levels and cognition $[74,75]$. However, further research is needed to elucidate the specific $A \beta$ oligomer species that may be more pathogenic in this disease.

To interpret the phenotypes in APP transgenic mouse models, it is necessary to untangle the effects of $A \beta$ over those from APP overexpression. To avoid potential artifacts due to APP overexpression, the $A p p^{\text {NL-F }}$ mouse 
model was created to augment $\mathrm{A} \beta 42$ without altering the APP expression level [76]. Specifically, this APP knockin mouse includes a humanized $A \beta$ region with two Swedish and Iberian mutations [76]. This model exhibited $\mathrm{A} \beta$ accumulation starting from an early age, likely resulting from increased $A \beta 42$. The integrated effects of APP proteolysis of Swedish and Iberian mutations led to elevated total $A \beta$ and $A \beta 42$, respectively [76]. The initial formation of amyloid plaques in the $A p p^{\mathrm{NL}-\mathrm{F}}$ mouse model was detected at 6 months [76]. Impairment of the working memory was observed at 18 months as detected in the Y maze, but there was no significant impairment in spatial learning and memory as detected by the Morris water maze (MWM) [76].

\section{Transgenic mice with Presenilin mutations}

In addition to APP mutations, previous evidence indicates that PS mutations, of which there are more than 200 mutations identified so far, also contribute to FAD pathology. PS mutations have been shown to cause an alteration of $\gamma$-cleavage in APP, which forms more amyloidogenic $A \beta 42$ peptides, thereby increasing the ratio of $A \beta 42: A \beta 40$ in the brain. Transgenic mice with mutant PS1 or PS2 were generated to study which PS mutations are implicated in AD pathology. Interestingly, although they exhibited AD pathological phenotypes, these models failed to develop amyloid plaques in their brains. The reduced $A \beta$ aggregation in these mouse models may be attributed to differences in $A \beta$ sequences between mice and humans [45]. Some PS1 mutant mouse models showed age-related neurodegeneration in the CA1 region and synaptic loss in the stratum radiatum region of the hippocampus [77-79]. The PS1 L286V transgenic mice, which displayed intracellular accumulation of A $\beta 40$ but lacked plaque development, had increase intracellular accumulation of $A \beta 42$ at 17-24 months [77].

Double transgenic mouse models have been widely used in the study of $A \beta$ pathology and evaluation of antiamyloid treatments. Double transgenic mouse models that exhibit sufficient $A \beta 42$ and have $A \beta$ plaque formation at an early age were generated by crossing human APP and presenilin transgenic lines [80]. Another important example of APP/PS1 double transgenic mouse model is 5XFAD mice, which co-express five FAD mutations. The 5XFAD mouse model can almost exclusively produce $A \beta 42$ and shows rapid accumulation of high levels of $\mathrm{A} \beta 42$ in the brain [81]. These mice had intraneuronal A 342 accumulation at the age of 1.5 months and subsequent amyloid deposition and gliosis, particularly in the subiculum and deep cortical layers, at 2 months [81]. Moreover, they also had significant neurodegeneration and neuronal loss, which appeared to be associated with the intraneuronal $\mathrm{A} \beta$ and amyloid plaques, respectively
[81]. To investigate amyloidogenic $A \beta 43$, another double transgenic mouse model was created by crossing APP transgenic mouse with PSA-M146V knock-in mouse. Interestingly, this mouse model showed an early increase in $A \beta 43$ levels at 3 months, as well as augmented $A \beta 42$ and A $\beta 40$ levels at 9 months. The APP23 x PS1-R278I mouse model exhibited robust progressive plaque deposition starting from the age of 6 months [82]. The APP23 x PS1-R278I mouse model also displayed shortterm memory decline at 3-4 months as shown by the Y maze, although spatial learning and memory remained largely intact [82]. These transgenes introduction contributed significantly to $A \beta$ pathology, as shown in the increased ratio of $\mathrm{A} \beta$ peptides and elevated $\mathrm{A} \beta 43$, followed by accelerated plaque deposition and cognitive impairment, suggesting alterations of these $A \beta$ peptides may be deleterious in AD.

To investigate the effects of some specific genes, the 5XFAD mouse model was crossed with other mouse lines to establish new mouse models. For example, the TREM2-BAC x 5XFAD mouse model was generated to probe TREM2, a microglia-enriched gene associated with a recessive disease named Nasu-Hakola disease, which is characterized by bone cysts and early dementia [83]. In addition, a subset of loss-of-function TREM2 variants was found to predispose a frontotemporal dementia-like syndrome in the absence of apparent bone involvement [84]. Given the shared disease manifestations, TREM2 biology in microglia may be involved in $\mathrm{AD}$ pathogenesis. To study the effect of the TREM2 gene in $\mathrm{AD}$ pathogenesis, several mouse models were generated including TREM2-BAC $\mathrm{x}$ 5XFAD [85], TREM2 Humanized (common variant) $x$ 5XFAD [86], and TREM2 Humanized (R47H) x 5XFAD [86]. The TREM2BAC x 5XFAD mice produced less cortical amyloid plaques than 5XFAD mice at 7 months and had similar performance in contextual fear conditioning tests compared to wildtype mice, indicating that TREM2 expression may somehow reduce the $A \beta$ pathology and alleviate cognitive decline in $\mathrm{AD}$ [85].

Other than double transgenic mouse models, which encompass mutations in two of the genes of interest in AD: APP and PS1 genes, a 3xTg-AD mouse model was generated to include mutations of human Tau (P301L), APP695 (KM670/671NL) and PS1 (M146V) [87]. The 3xTg-AD mice exhibited severely impaired long-term potentiation, which was thought to be mediated by intracellular $A \beta$ accumulation at the age of 6 months [87]. Such $A \beta$ pathology was wide spread across brain regions (hippocampus, amygdala, frontal cortex, thalamus), and was also demonstrated to underlie the behavioral deficits observed in contextual fear conditioning and MWM, as $\mathrm{A} \beta$ clearance enhanced by the administration of anti-A $\beta$ antibody successfully reversed the long-term spatial 
memory impairment observed in MWM [88]. A recent study further confirmed 6-month old as the age of onset for cognitive deficits and signs of neuroinflammation as represented by a significantly higher degree of microglia activation [89]. Although 3xTg-AD mice carry mutations in three different genes that were thought to contribute synergistically to the neuropathology of $\mathrm{AD}[90,91]$, the fact that $\mathrm{A} \beta$ deposits were observed prior to neurofibrillary alterations suggests that $\mathrm{A} \beta$ pathology remains the major driving force of disease manifestation in $\mathrm{AD}$.

Table 1. Mouse models of amyloid-beta pathology in Alzheimer's disease.

\begin{tabular}{|c|c|c|c|c|c|c|}
\hline $\begin{array}{l}\text { Animal } \\
\text { model }\end{array}$ & $\begin{array}{l}\text { Model } \\
\text { background }\end{array}$ & Transgene & Amyloid pathology & Other pathology & Behavioral test & Ref. \\
\hline Tg2576 & C57BL/6 & $\begin{array}{l}\text { Human APP695 } \\
\text { (Swedish) }\end{array}$ & $\begin{array}{l}\text { A } \beta \text { plaques at } 10-12 \\
\text { months, oligomeric } \\
\mathrm{A} \beta \text { generation }\end{array}$ & $\begin{array}{l}\text { Synaptic loss at } 15-18 \\
\text { months. }\end{array}$ & $\begin{array}{l}\text { Behavioral impairment in } \\
\text { novel object recognition at } \\
12-15 \text { months, Morris } \\
\text { water maze at } 6 \text { months } \\
\text { and Y maze at } 10 \text { months. }\end{array}$ & $\begin{array}{l}{[55} \\
123 \\
237]\end{array}$ \\
\hline TgAPP23 & C57BL/6J & $\begin{array}{l}\text { Human APP751 } \\
\text { (Swedish) }\end{array}$ & $\begin{array}{l}\text { A } \beta \text { plaques at } 6 \\
\text { months }\end{array}$ & $\begin{array}{l}\text { Increased level of } \\
\text { phospho-tau at } 6 \\
\text { months, phospho-tau } \\
\text { deposition surrounding } \\
\text { plaques at } 12 \text { months, } \\
\text { neuronal loss in area of } \\
\text { CA1 at } 14-18 \text { months. }\end{array}$ & $\begin{array}{l}\text { Behavioral impairment in } \\
\text { novel object recognition at } \\
3-4 \text { months, Morris water } \\
\text { maze at } 3 \text { months. }\end{array}$ & $\begin{array}{l}{[56,} \\
238 \\
239]\end{array}$ \\
\hline PDAPP & $\begin{array}{l}\text { Swiss Webster } \times \\
\text { B6D2F1 }\end{array}$ & $\begin{array}{l}\text { Human APP } \\
\text { (Indiana) }\end{array}$ & $\begin{array}{l}\mathrm{A} \beta \text { plaques at } 6-9 \\
\text { months }\end{array}$ & Synaptic loss. & $\begin{array}{l}\text { Behavioral impairment in } \\
\text { novel object recognition at } \\
6 \text { months, Morris water } \\
\text { maze at } 3 \text { months. }\end{array}$ & $\begin{array}{l}{[54,} \\
240]\end{array}$ \\
\hline $\mathbf{J} 20$ & $\begin{array}{l}\text { C57BL/6 } \times \\
\text { DBA/2 F2 }\end{array}$ & $\begin{array}{l}\text { Human APP } \\
\text { (Swedish and } \\
\text { Indiana) }\end{array}$ & $\begin{array}{l}\text { Diffuse amyloid } \\
\text { deposits at 5-6 months } \\
\text { and larger neuritic } \\
\text { plaques at } 9 \text { months }\end{array}$ & $\begin{array}{l}\text { Phospho- } \\
\text { neurofilaments. }\end{array}$ & $\begin{array}{l}\text { Behavioral impairment in } \\
\text { novel object recognition at } \\
4 \text { months, Morris water } \\
\text { maze at } 6-9 \text { months. }\end{array}$ & $\begin{array}{l}{[53,} \\
68, \\
241 \\
242]\end{array}$ \\
\hline TgCRND8 & $\begin{array}{l}\mathrm{C} 3 \mathrm{H} / \mathrm{He} \times \\
\mathrm{C} 57 \mathrm{BL} / 6\end{array}$ & $\begin{array}{l}\text { Human APP695 } \\
\text { (Swedish and } \\
\text { Indiana) }\end{array}$ & $\begin{array}{l}\text { A } \beta \text { plaques at } 3 \\
\text { months, dense core } \\
\text { plaques at } 5 \text { months, } \\
\text { spreading to the } \\
\text { cerebellum and } \\
\text { brainstem by } 8- \\
9 \text { months }\end{array}$ & $\begin{array}{l}\text { Astrocytic gliosis and } \\
\text { microglial activation in } \\
\text { regions around } \\
\text { plaques. }\end{array}$ & $\begin{array}{l}\text { Behavioral impairment in } \\
\text { novel object recognition at } \\
3-5 \text { months, Morris water } \\
\text { maze at } 3 \text { months. }\end{array}$ & $\begin{array}{l}{[67,} \\
69, \\
243]\end{array}$ \\
\hline$A p p^{\mathrm{NL}-\mathrm{F}}$ & $\mathrm{C} 57 \mathrm{BL} / 6$ & $\begin{array}{l}\text { Human APP } \\
\text { (Swedish and } \\
\text { Iberian) }\end{array}$ & $\mathrm{A} \beta$ plaque at 6 months & $\begin{array}{l}\text { Synaptic loss, } \\
\text { microgliosis and } \\
\text { astrocytosis }\end{array}$ & $\begin{array}{l}\text { Behavioral impairment in } \\
\text { Y-maze at } 18 \text { months, no } \\
\text { impairment in Morris } \\
\text { water maze at } 18 \text { months }\end{array}$ & [76] \\
\hline 5XFAD & $\begin{array}{l}\operatorname{Tg} 6799 \times \operatorname{Tg} 7031 \\
\times \operatorname{Tg} 7092\end{array}$ & $\begin{array}{l}\text { Human APP } \\
\text { (Swedish, Florida, } \\
\text { London); Human } \\
\text { PS1 (M146L, } \\
\text { L286V) }\end{array}$ & $\begin{array}{l}\text { Intraneuronal } \mathrm{A} \beta 42 \\
\text { accumulation at } 1.5 \\
\text { months, amyloid } \\
\text { deposition, gliosis, at } \\
2 \text { months }\end{array}$ & $\begin{array}{l}\text { Significant } \\
\text { neurodegeneration and } \\
\text { neuronal loss. }\end{array}$ & $\begin{array}{l}\text { Behavioral impairment in } \\
\text { Y-maze at } 4-5 \text { months, } \\
\text { decreased Interest in } \\
\text { social-related behaviors at } \\
3-12 \text { months. Morris water } \\
\text { maze at } 4 \text { months. }\end{array}$ & $\begin{array}{l}{[81,} \\
244, \\
245]\end{array}$ \\
\hline $\begin{array}{l}\text { APP23 x } \\
\text { PS1-R278I }\end{array}$ & C57BL/6J & $\begin{array}{l}\text { Human APP23 } \\
\text { (Swedish K651N, } \\
\text { M652L); Human } \\
\text { PS1 (R278I) }\end{array}$ & $\mathrm{A} \beta$ plaque at 6 months & Astrocytosis. & $\begin{array}{l}\text { Behavioral impairment in } \\
\text { Y-maze at 3-4 months; no } \\
\text { significant impairment in } \\
\text { Morris water maze }\end{array}$ & {$[82]$} \\
\hline $\begin{array}{l}\text { TREM2- } \\
\text { BAC } x \\
\text { 5XFAD }\end{array}$ & $\begin{array}{l}\text { TREM2-BAC: } \\
\text { FVB/NJ; } \\
\text { 5XFAD: } \\
\text { C57BL/6X SJL }\end{array}$ & $\begin{array}{l}\text { Human APP } \\
\text { (Swedish, Florida, } \\
\text { London); Human } \\
\text { PS1 (M146L, } \\
\text { L286V) }\end{array}$ & $\begin{array}{l}\text { less cortical amyloid } \\
\text { plaque at } 7 \text { months } \\
\text { compared to 5XFAD } \\
\text { mice }\end{array}$ & $\begin{array}{l}\text { Enhanced process } \\
\text { ramification and } \\
\text { phagocytic marker } \\
\text { expression in plaque- } \\
\text { associated microglia; } \\
\text { improved dystrophic } \\
\text { neurites. }\end{array}$ & $\begin{array}{l}\text { No cognitive impairment } \\
\text { in contextual fear } \\
\text { conditioning test. }\end{array}$ & {$[85]$} \\
\hline 3xTg-AD & C57BL6/129SvJ & $\begin{array}{l}\text { Human APP } \\
\text { (Swedish); } \\
\text { Human PS1 } \\
\text { (M146V); Human } \\
\text { Tau (P301L) }\end{array}$ & $\mathrm{A} \beta$ plaque at 6 months & $\begin{array}{l}\text { synaptic dysfunction } \\
\text { and increased } \\
\text { microglia activation at } \\
6 \text { months; Tau } \\
\text { alteration at } 12-15 \\
\text { months }\end{array}$ & $\begin{array}{l}\text { Retention deficits in } \\
\text { Morris water maze and } \\
\text { contextual fear memory }\end{array}$ & $\begin{array}{l}{[87-} \\
89]\end{array}$ \\
\hline
\end{tabular}




\section{Amyloid-beta pathology in rat models}

\section{UKUR25 and UKUR28 rats}

The first transgenic rat model of $\mathrm{AD}$ displayed intracellular amyloid-beta accumulation but without senile plaques. The UKUR25 model with human APP 751 and PS1 transgenes and the UKUR28 model with mutated human APP 751 transgene were both reported to display intracellular accumulation of $A \beta$ peptides in the cerebral cortex and hippocampus at the age of 6 months corresponding to the "pre-plaque" stage in AD [92]. Interestingly, aged rats in both transgenic lines did not have senile plaques at 24 months [92]. One possible explanation of such findings was that the $A \beta$ levels were not sufficient to initiate the deposition and subsequent senile plaque formation. As shown by behavioral tests, both transgenic models displayed a mild decline in spatial acquisition learning at 16 months [93]. Downstream molecular analysis revealed that intracellular accumulation of $A \beta$ could induce the activation of the mitogen-activated protein kinase (MAPK) ERK2 and phosphorylation of tau proteins at the PHF-tau epitope [92], indicating that $A \beta$ peptides may be an essential component that drives the diverse pathogenesis of $\mathrm{AD}$.

\section{APPswe rat}

The first APP transgenic rat model, APPswe, was created in 2004 by Ruiz-Opazo [94]. To generate the APPswe rat model, Swedish mutated APP expression driven by the platelet-derived growth factor promoter was introduced into a background strain of Fisher-344 rats [95]. The transgenic APPswe rats displayed increased intracerebral APP mRNA and elevated levels of $A \beta 42$ and $A \beta 40$ peptide at 12 months [94]. Surprisingly, 6- and 12-monthold APPswe rats demonstrated enhanced cognitive performance in hippocampus-dependent behavioral tests, including MWM and Social Transmission of Food Preference (STFP) task [94]. These results indicate that APP and its derivatives may have potential roles in learning and memory functions. Further research on this transgenic model may provide insights on the effects of intracerebral APP level on memory.

\section{Tg6590 rat}

The transgenic Tg6590 rat expressing the human APP with Swedish mutation was developed in 2007 by Folkesson [96]. Molecular characterization of this rat model showed increased levels of $A \beta 40$ and $A \beta 42$ in the hippocampus and cortex at 9 months, and subsequent $A \beta$ deposition mainly in the cerebrovascular blood vessels at 11 months [97]. Notably, 9-month-old Tg6590 rats showed impaired spatial learning and memory in the MWM and reduced exploratory behaviors in the Open Field Test (OFT), which manifested prior to $A \beta$ deposition [97]. The observation of behavioral deficits preceding the onset of $A \beta$ pathology indicates that $A \beta$ formation may not be necessarily linked with cognition. More investigations are needed on the transgenic $\operatorname{Tg} 6590$ rat model to fully understand the importance of this finding in $\mathrm{AD}$ pathology.

\section{hAPP695 rat}

The hAPP isoform 695 ( $h A P P 695)$ is recognized as a specific APP isoform preferentially expressed by neurons. Previous clinical studies showed reduced APP695 transcripts in post-mortem brains of AD patients [98]. To further elucidate the role of this isoform in $\mathrm{AD}$ pathology, its gene was introduced into the genome of wildtype rats to generate the $h A P P 695$ model. The transgenic $h A P P 695$ rat had a two-fold increase in APP level in the hippocampus and cortex [99], indicating this transgene partly mediates $A \beta$ pathology in AD. Further behavioral characterization of hAPP695 rats showed impaired locomotor and spatial learning and memory after middle cerebral artery occlusion [99]. Moreover, a few studies suggested that enhanced APP/A $\beta$ may lead to altered brain function, such as impaired skill [100] and spatial learning [101], and was possibly associated with negative effects on cognition. This further substantiated the detrimental effects of transgene mutation / introduction in AD animal models. Interestingly, previous evidence showed that APP and/or $A \beta$ accumulation was increased in rodents after inducing ischemia $[102,103]$, which may imply a possible compensation effect of APP/A $\beta$ from brain damage. Therefore, the aforementioned findings from $h A P P 695$ rat may offer a different opinion on the effect of $A P P / A \beta$ on brain structural damage [99].

\section{APP21 and APP31 rats}

Two APP-transgenic rat lines, APP21 and APP31, were generated using Fischer 344 rats by lentiviral vector infection of Fischer 344 zygotes. In a previous study, APP21 rats were found to have a serum A $\beta 42$ level of 135 $\mathrm{pg} / \mathrm{mL}$, and both APP21 and APP31 rats had APP mRNA levels that were 7.6 and 3 times more than in wildtype rats, respectively [104]. Additionally, the immunehistochemistry showed the human APP transgene was expressed in neurons, but not in glial cells [104]. The transgenic APP21 rats showed impaired spatial memory in the MWM test at an early age of 3 months, but did not show deteriorated long-term memory recall ability with age, similar to that of wildtype rats [105]. 


\section{PSAPP rat}

In 2007, Flood et al. reported a series of new transgenic rat models that were generated by crossing two SpragueDawley rat lines with different transgene expressions of human APP [106]. This transgenic process gave rise to rat models that expressed single, double, or triple transgenes denoted by their carried mutations: $\mathrm{Tg} 478$ rats expressed human APP with Swedish mutation driven by rat synapsin promoter, Tg1116 rats expressed a human APP minigene with Swedish and Indiana FAD mutations, and Tg11587 rats expressed Swedish and Finnish FAD mutations. The resulting double homozygous rats displayed adequate levels of $A \beta$ accumulation to form amyloid deposition at the age of 17 to 18 months. Crossing with a third transgenic rat carrying a human PS-1 transgene with the familial AD mutation M146V (Tg11587) reduced the progression time, with $\mathrm{A} \beta$ deposition observed at 7 months. A triple homozygous transgenic rat, which included three transgene expressions (Tg478/Tg1116/Tg11587), also known as PSAPP rat, had $A \beta$ deposition similar to that found in mouse models [107]. The PSAPP rat also displayed cognitive impairment in the MWM at 7 months, but showed no changes in anxiety and locomotion in the elevated plus maze and OFT [107]. However, PSAPP rats overexpressing numerous transgenes are vulnerable to many diseases such as chronic kidney disease and hypertension [108].

\section{TgF344-AD rat}

The transgenic (Tg) F344-AD rat model expresses both human APP (APPswe) and PS1 (PS1 $\triangle \mathrm{E} 9$ ) genes, which are both independent factors in early-onset familial AD. This rat model was found to have age-related cerebral $A \beta$ accumulation that induced a tauopathy, together with cognitive impairment, apoptosis, and neuron loss [109]. The TgF344-AD rat exhibited reversal learning declines in the MWM at 6 months [110] and learning deficits in the Barnes maze at 15 months [109]. Compared with other models that had limited neuron loss, TgF344-AD rats displayed persistent and severe neuron loss in the cortex and hippocampus, together with shrinking hemispheric brain and spongiform-like vacuolar pathology of aged rats [109]. The NFT pathology in TgF344-AD rats was found to involve endogenous rat tau protein compared to animal models of AD based on the mutated human tau transgene [109]. Overall, these results demonstrated that the TgF344-AD rat model had significant progressive neurodegeneration, further supporting this rat model as a promising animal model for the future AD research.

\section{McGill-R-Thy1-APP rat}

The transgenic McGill-R-Thy1-APP rat expresses human APP with Swedish and Indiana mutations driven by the murine Thy 1.2 promoter. The McGill-R-Thy1-APP rat showed a gradual increase in $A \beta$ accumulation in the cortex and hippocampus at 1 week postnatally [111]. Amyloid plaque formation associated with the activation of glial cells and dystrophy of surrounding neurites was detected at 6 months [111]. Interestingly, despite the absence of plaque generation at 3 months, this rat model exhibited spatial learning and memory impairments in the MWM dependent on the soluble cortical A $\beta$ level, which became more severe at 13 months [111]. Another study on the McGill-R-Thy1-APP rat showed similar findings, which supports the validity of this transgenic rat model. These transgenic rats exhibited spatial cognitive deficiency at 4, 6, and 12 months. Moreover, the rats were observed to have working memory decline in the Y maze, as well as higher anxiety levels in the OFT at 6 and 12 months [112].

\section{APP+PS1 rat}

The APP+PS1 rat expressing human APP with Swedish and Indiana mutations and human PS1 with L166P mutation was generated by injecting a lentiviral vector containing PSEN1 into the fertilized egg of homozygous APP21 rats [113]. Compared to APP21 rats, APP+PS1 rats had approximately two times the level of $A \beta$ and more severe amyloid pathology, as well as memory and learning deficits that resembled AD [113]. At 10 months, APP+PS1 rats displayed cognitive declines in various areas such as acquisition, retention, and reversal phase as shown in the Barnes maze task [113]. At 19 months, female APP+PS1 rats were found to have amyloid deposits and cerebral amyloid pathology [114].

\section{Advantages of rodent models in AD}

Given the ethical considerations as well as the late manifestation of symptoms in $\mathrm{AD}$ patients, clinical investigation of $\mathrm{AD}$ pathogenesis is challenging. Transgenic rodent models of AD could be an effective alternative approach for studying the pathological processes. Furthermore, animal models allow us to perform in-depth terminal studies in different age groups for a better understanding of disease progression and the molecular mechanisms contributing to the pathogenesis. Models that successfully mimic the pathogenesis of $\mathrm{AD}$ could also be employed to screen potential therapeutic agents in preclinical settings. Transgenic animal models can also be used in animal behavior testing to validate treatment efficacy. The use of transgenic animal models for disease research also provides translational value. For 
instance, transgenic mouse models were shown to be phylogenetically conserved with humans in terms of the architecture and function of the hippocampal and entorhinal cortex circuits, sharing similar numbers of genes and considerable chromosomal synteny. Despite the difficulty in generating transgenic rat models, they can be a viable option in the research of highly conserved physiological, morphological, and genetic conditions similar to human diseases [115-117]. For example, the apoE amino sequences between human and rat are quite homologous, sharing $73.5 \%$ and $73.9 \%$ of human apoE3 and apoE4, respectively $[118,119]$.

Table 2. Rat models of amyloid-beta pathology in Alzheimer's disease.

\begin{tabular}{|c|c|c|c|c|c|c|}
\hline $\begin{array}{l}\text { Animal } \\
\text { model }\end{array}$ & $\begin{array}{l}\text { Model } \\
\text { background }\end{array}$ & Transgene & Amyloid pathology & Other pathology & Behavioral test & Ref. \\
\hline Tg2576 & C57BL/6 & $\begin{array}{l}\text { Human APP695 } \\
\text { (Swedish) }\end{array}$ & $\begin{array}{l}\text { A } \beta \text { plaques at } 10-12 \\
\text { months, oligomeric } \\
\text { A } \beta \text { generation }\end{array}$ & $\begin{array}{l}\text { Synaptic loss at } 15-18 \\
\text { months. }\end{array}$ & $\begin{array}{l}\text { Behavioral impairment in } \\
\text { novel object recognition } \\
\text { at } 12-15 \text { months, Morris } \\
\text { water maze at } 6 \text { months } \\
\text { and Y maze at } 10 \text { months. }\end{array}$ & $\begin{array}{l}{[55} \\
123 \\
237]\end{array}$ \\
\hline TgAPP23 & $\mathrm{C} 57 \mathrm{BL} / 6 \mathrm{~J}$ & $\begin{array}{l}\text { Human APP751 } \\
\text { (Swedish) }\end{array}$ & $\begin{array}{l}\mathrm{A} \beta \text { plaques at } 6 \\
\text { months }\end{array}$ & $\begin{array}{l}\text { Increased level of } \\
\text { phospho-tau at } 6 \text { months, } \\
\text { phospho-tau deposition } \\
\text { surrounding plaques at } 12 \\
\text { months, neuronal loss in } \\
\text { area of CA1 at } 14-18 \\
\text { months. }\end{array}$ & $\begin{array}{l}\text { Behavioral impairment in } \\
\text { novel object recognition } \\
\text { at 3-4 months, Morris } \\
\text { water maze at } 3 \text { months. }\end{array}$ & $\begin{array}{l}{[56,} \\
238, \\
239]\end{array}$ \\
\hline PDAPP & $\begin{array}{l}\text { Swiss Webster } \times \\
\text { B6D2F1 }\end{array}$ & $\begin{array}{l}\text { Human APP } \\
\text { (Indiana) }\end{array}$ & $\begin{array}{l}\mathrm{A} \beta \text { plaques at } 6-9 \\
\text { months }\end{array}$ & Synaptic loss. & $\begin{array}{l}\text { Behavioral impairment in } \\
\text { novel object recognition } \\
\text { at } 6 \text { months, Morris water } \\
\text { maze at } 3 \text { months. }\end{array}$ & $\begin{array}{l}{[54,} \\
240]\end{array}$ \\
\hline $\mathbf{J} 20$ & $\begin{array}{l}\text { C57BL/6 } \times \\
\mathrm{DBA} / 2 \mathrm{~F} 2\end{array}$ & $\begin{array}{l}\text { Human APP } \\
\text { (Swedish and } \\
\text { Indiana) }\end{array}$ & $\begin{array}{l}\text { Diffuse amyloid } \\
\text { deposits at 5-6 } \\
\text { months and larger } \\
\text { neuritic plaques at } 9 \\
\text { months }\end{array}$ & Phospho-neurofilaments. & $\begin{array}{l}\text { Behavioral impairment in } \\
\text { novel object recognition } \\
\text { at } 4 \text { months, Morris water } \\
\text { maze at } 6-9 \text { months. }\end{array}$ & $\begin{array}{l}{[53} \\
68 \\
241 \\
242]\end{array}$ \\
\hline TgCRND8 & $\begin{array}{l}\mathrm{C} 3 \mathrm{H} / \mathrm{He} \times \\
\mathrm{C} 57 \mathrm{BL} / 6\end{array}$ & $\begin{array}{l}\text { Human APP695 } \\
\text { (Swedish and } \\
\text { Indiana) }\end{array}$ & $\begin{array}{l}\text { A } \beta \text { plaques at } 3 \\
\text { months, dense core } \\
\text { plaques at } 5 \text { months, } \\
\text { spreading to the } \\
\text { cerebellum and } \\
\text { brainstem by } 8- \\
9 \text { months }\end{array}$ & $\begin{array}{l}\text { Astrocytic gliosis and } \\
\text { microglial activation in } \\
\text { regions around plaques. }\end{array}$ & $\begin{array}{l}\text { Behavioral impairment in } \\
\text { novel object recognition } \\
\text { at } 3-5 \text { months, Morris } \\
\text { water maze at } 3 \text { months. }\end{array}$ & $\begin{array}{l}{[67,} \\
69 \\
243]\end{array}$ \\
\hline$A p p^{\mathrm{NL}-\mathrm{F}}$ & C57BL/6 & $\begin{array}{l}\text { Human APP } \\
\text { (Swedish and } \\
\text { Iberian) }\end{array}$ & $\begin{array}{l}\text { A } \beta \text { plaque at } 6 \\
\text { months }\end{array}$ & $\begin{array}{l}\text { Synaptic loss, } \\
\text { microgliosis and } \\
\text { astrocytosis }\end{array}$ & $\begin{array}{l}\text { Behavioral impairment in } \\
\text { Y-maze at } 18 \text { months, no } \\
\text { impairment in Morris } \\
\text { water maze at } 18 \text { months }\end{array}$ & [76] \\
\hline 5XFAD & $\begin{array}{l}\operatorname{Tg} 6799 \times \operatorname{Tg} 7031 \\
\times \operatorname{Tg} 7092\end{array}$ & $\begin{array}{l}\text { Human APP } \\
\text { (Swedish, } \\
\text { Florida, London); } \\
\text { Human PS1 } \\
\text { (M146L, L286V) }\end{array}$ & $\begin{array}{l}\text { Intraneuronal } \mathrm{A} \beta 42 \\
\text { accumulation at } 1.5 \\
\text { months, amyloid } \\
\text { deposition, gliosis, at } \\
2 \text { months }\end{array}$ & $\begin{array}{l}\text { Significant } \\
\text { neurodegeneration and } \\
\text { neuronal loss. }\end{array}$ & $\begin{array}{l}\text { Behavioral impairment in } \\
\text { Y-maze at } 4-5 \text { months, } \\
\text { decreased Interest in } \\
\text { social-related behaviors } \\
\text { at 3-12 months. Morris } \\
\text { water maze at } 4 \text { months. }\end{array}$ & $\begin{array}{l}{[81} \\
244, \\
245]\end{array}$ \\
\hline $\begin{array}{l}\text { APP23 x } \\
\text { PS1-R278I }\end{array}$ & $\mathrm{C} 57 \mathrm{BL} / 6 \mathrm{~J}$ & $\begin{array}{l}\text { Human APP23 } \\
\text { (Swedish K651N, } \\
\text { M652L); Human } \\
\text { PS1 (R278I) }\end{array}$ & $\begin{array}{l}\text { A } \beta \text { plaque at } 6 \\
\text { months }\end{array}$ & Astrocytosis. & $\begin{array}{l}\text { Behavioral impairment in } \\
\text { Y-maze at 3-4 months; no } \\
\text { significant impairment in } \\
\text { Morris water maze }\end{array}$ & {$[82]$} \\
\hline $\begin{array}{l}\text { TREM2- } \\
\text { BAC X } \\
\text { 5XFAD }\end{array}$ & $\begin{array}{l}\text { TREM2-BAC: } \\
\text { FVB/NJ; } \\
\text { 5XFAD: } \\
\text { C57BL/6X SJL }\end{array}$ & $\begin{array}{l}\text { Human APP } \\
\text { (Swedish, } \\
\text { Florida, London); } \\
\text { Human PS1 } \\
\text { (M146L, L286V) }\end{array}$ & $\begin{array}{l}\text { less cortical amyloid } \\
\text { plaque at } 7 \text { months } \\
\text { compared to 5XFAD } \\
\text { mice }\end{array}$ & $\begin{array}{l}\text { Enhanced process } \\
\text { ramification and } \\
\text { phagocytic marker } \\
\text { expression in plaque- } \\
\text { associated microglia; } \\
\text { improved dystrophic } \\
\text { neurites. }\end{array}$ & $\begin{array}{l}\text { No cognitive impairment } \\
\text { in contextual fear } \\
\text { conditioning test. }\end{array}$ & {$[85]$} \\
\hline 3xTg-AD & C57BL6/129SvJ & $\begin{array}{l}\text { Human APP } \\
\text { (Swedish); } \\
\text { Human PS1 } \\
\text { (M146V); } \\
\text { Human Tau } \\
\text { (P301L) }\end{array}$ & $\begin{array}{l}\text { A } \beta \text { plaque at } 6 \\
\text { months }\end{array}$ & $\begin{array}{l}\text { synaptic dysfunction and } \\
\text { increased microglia } \\
\text { activation at } 6 \text { months; } \\
\text { Tau alteration at } 12-15 \\
\text { months }\end{array}$ & $\begin{array}{l}\text { Retention deficits in } \\
\text { Morris water maze and } \\
\text { contextual fear memory }\end{array}$ & [87-89] \\
\hline
\end{tabular}




\section{Human APP751}
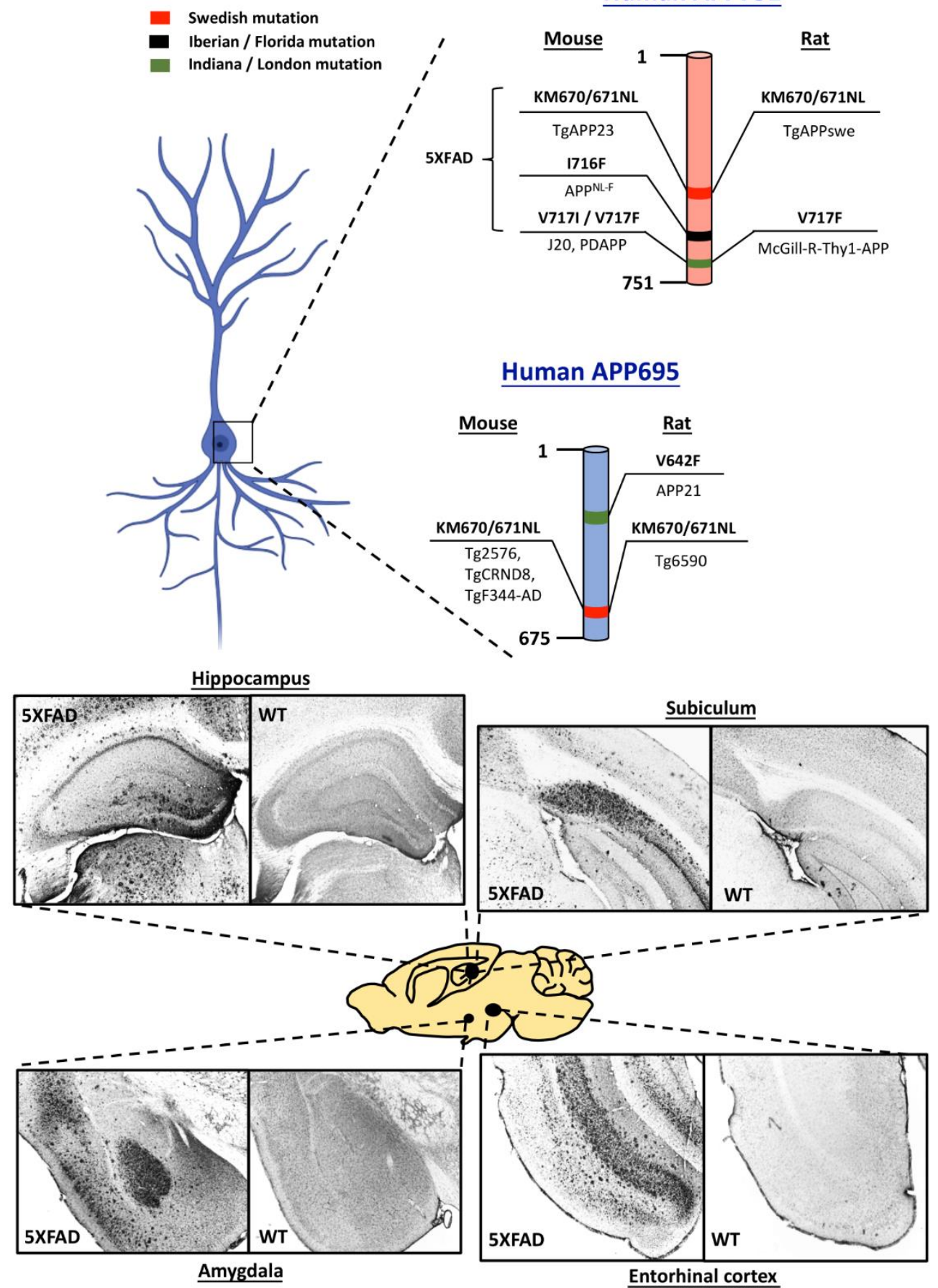

Figure 2. Human APP695 and APP751 are essential genes involved in the generation of transgenic rodent models of Alzheimer's disease (AD). Swedish (red), Iberian / Florida (Black) and Indiana / London (Green) are the major mutations introduced into the human APP in rodents to induce rapid amyloid plaque formation. One of the rodent models that encompass numerous mutations is 5XFAD, 3 mutations of which are located on human APP751. Representative photomicrographs showing intense amyloid plaque formation in various brain regions demonstrate severe $\mathrm{A} \beta$ pathology in 5XFAD mouse model in the age of 6 months. These images highlight the $A \beta$ pathological progression in brain regions established for memory processes. 
The findings from studies using transgenic rats suggest they could be used in the structural analysis of the $\mathrm{AD}$ brain. Moreover, given their larger size compared to mice, rats would be a better choice for complicated procedures, such as the intraventricular injections, acquisition of cerebrospinal fluid, electrophysiology, neuroimaging, and neurosurgical measures [120]. In addition, their size also allows fine molecular manipulation to be performed in vivo. In terms of their behavior, rats exhibit more complex social behaviors, including juvenile fighting, courtship behaviors, and lowlevel aggressive behaviors [121]. Notably, rats have been shown to be less stressed in some behavioral memory paradigms that utilize water such as the MWM [121]. A stable mental state is essential for valid and reliable behavioral outcomes in behavioral testing of animals.

Despite the lack of animal models that exhibit disease development fully resembling that of human $\mathrm{AD}$, the abovementioned animal models were found to consistently reflect the pathology of $\mathrm{A} \beta$ accumulation and/or amyloid plaques formation. The question of whether $A \beta$ is the sole driving force in $A D$ pathogenesis remains unanswered. Thus, further investigations using a well-establish animal model that encompasses the major $\mathrm{AD}$ pathologies is still needed. Nonetheless, with advancements in current genetic research and disease models, we are optimistic that a more comprehensive model can be developed that can elucidate the underlying relationship between $\mathrm{A} \beta$ and $\mathrm{AD}$.

\section{Limitations of rodent models in AD}

Although research using animal models has yielded promising results, their clinical translational value remains ambiguous. Currently, 132 agents have been evaluated in clinical trials, including 88 agents in 42 phase 3 trials, 74 agents in 83 phase 2 trials, and 30 agents in 31 phase 1 trials [122]. In disease modification trials of 96 agents, 38 agents focused on amyloid as the primary target or one of the main targets [122]. In particular, amyloid was the most common target of disease modification studies in phase 2 and 3 trials [122]. Although many agents have been evaluated in clinical trials, none of them has yet to be applied as a clinical treatment. The possible underlying reasons for the failure of these agents include (i) a lack of understanding of the neurobiological basis of $\mathrm{AD}$ resulting in the neuroprotective treatment failing to target crucial factors, (ii) the inability of current $\mathrm{AD}$ animal models to completely mimic $\mathrm{AD}$ pathology resulting in incompatible findings between preclinical and clinical phases, and (iii) insufficient treatment length in the trials, considering $\mathrm{AD}$ is a chronic neurodegenerative disease that may require long-term pharmacological treatment and regular monitoring. Furthermore, strict regulations should be implemented for testing drugs to maintain high safety and low side effects, and the risk/benefits should also be fully considered. However, all these factors cannot be completely addressed by preclinical animal models, and there are certain limitations in the use of transgenic animal models in $\mathrm{AD}$ research.

The effectiveness of a transgenic animal model in mimicking certain diseases relies heavily on how they respond in behavioral assessments. Behavioral findings from many studies employing transgenic rat models are relatively reliable, as the behavioral tests demonstrate rats have consistent behavior. However, we observed varying results from studies using $\mathrm{AD}$ mouse models. This phenomenon may stem from the emotional vulnerability of mice to stress and novel environments, which hinders their normal cognitive ability during testing. Furthermore, some rodent models did not show cognitive declines in the behavioral testing, which questions the validity of these models. This warrants further investigation with a more controlled behavioral testing paradigm. Most of the studies employed rodent models that exhibited increased $A \beta$ levels and/or plaque formation as the only disease manifestation, which does not reflect the full pathology of AD. For example, Tg2576 and PS1/APP mouse models failed to mimic the neuron loss, which is one of the hallmarks of $\mathrm{AD}[55,123]$. Moreover, the age and gene background of the animal model as well as the experimental conditions can greatly impact the research outcomes [124]. This highlights the importance of more reliable neuroscientific methodology in disease research.

Another hypothesis of $A \beta$ plaque formation suggests that $A \beta$ accumulation is a defense mechanism against other pathologies including cellular dysfunction and dysregulation, but this has yet to be fully investigated [124]. Given the contradictory role of $A \beta$, researchers should consider the advantages and limitations of the different animal models and choose the most appropriate one.

\section{Exploring therapeutic options using rodent models of AD}

Currently, treatments only focus on alleviating major disease symptoms of AD. However, these treatments become ineffective in the later stages of $\mathrm{AD}$ as the severity of the disease has escalated. Due to the late manifestation of symptoms and ethical constraints, it is difficult to conduct accurate clinical evaluations in $\mathrm{AD}$ patients. Thus, animal models can provide valuable information to elucidate the pathological progression of $\mathrm{AD}$ and facilitate the discovery of potential pharmacological treatments that may later translate to the clinical setting. In this section, we discuss components of 
$\mathrm{AD}$ pathology as possible viable targets for disease modulation.

\section{Neuroinflammation}

It was generally accepted that the brain was immunologically privileged due to the presence of the blood-brain barrier (BBB), which prevents immune cells and humoral factors from entering the nervous system. It was also generally recognized that brain cells were incapable of eliciting an immune response. However, this idea was challenged by several discoveries in the past two decades, in that disruption of the BBB was consistently reported in $\mathrm{AD}$ cases [125]. Epidemiological investigations have revealed the role of neuroinflammation in the brain. Likewise, research has shown that brain tissues can change their innate paracrine systems through autonomously-generated and regulated inflammatory molecules [126]. Given the role of inflammation in the pathogenesis of brain diseases such as $\mathrm{AD}$, several anti-inflammatory treatments have been investigated. For example, chronic administration of nonsteroidal anti-inflammatory drugs (NSAIDs) was found to reduce the risk of developing $\mathrm{AD}$ by $80 \%$ in populations over 55 years of age without a history of dementia prior to evaluation [127]. Although neuroinflammation is an integral factor in $\mathrm{AD}$ pathogenesis, it is important to identify the agents that play a major role in this process.

Actrocytes are an important component in the process of neuroinflammation. Reactive astrogliosis, which is a multi-phase remodeling of astrocytes, is beneficial for neuronal protection and recovery of impaired neural tissues [128, 129]. In addition to activated microglia, activated astrocytes, which become hypertrophic, gradually accumulate and surround senile plaques in the brains of AD patients. Activation of glial cells can also occur in the early stage of $\mathrm{AD}$, sometimes even prior to the formation of $A \beta$ deposition [130]. Although reactive astrocytes are characterized by their functional decline and increased expression of glial fibrillary acidic proteins [131], their domain organization was found to be maintained and there was no evidence of scar generation. In animal models of AD, early features include astroglial atrophy, which may significantly reduce synapse coverage and possibly underlies the impaired neurotransmission and cognitive deficits observed in $\mathrm{AD}$ [33, 131-134]. Furthermore, this atrophy suggested a spatio-temporal pattern of disease progression, with signs of atrophy first observed in the area of entorhinal cortex in early $\mathrm{AD}$ and subsequently affecting astrocytes located far away from the senile plaques in late AD. Similar to microglia, when astrocytes are exposed to $A \beta$, they start to release cytotoxic molecules such as cytokines, interleukins, and NO. Such reactions then aggravate the neuroinflammation throughout the course of $\mathrm{AD}$. Previous studies in an animal model of $\mathrm{AD}$, which employed adeno-associated virus-driven suppression of the molecular cascade that indirectly inhibited astrocyte activation, revealed they had decreased $A \beta$ deposition [135]. Such suppression also restored cognitive abilities and reduced astrogliosis [135], indicating that astroglial activation could be modulated to alleviate this disease. Moreover, the clearance of $\mathrm{A} \beta$ induced by astrocytes was dependent on apoE60, and astrocyte-associated lipidation might enhance other mechanisms of $A \beta$ clearance such as microglia-mediated elimination of $A \beta[136,137]$. Indeed, astrocytes were found to promote internalization and degeneration of $\mathrm{A} \beta$ in in vitro experiments [138]. The above evidence suggests that astrocytes are essential for the clearance of $A \beta$.

Microglia are widely distributed in the central nervous system (CNS) and are known to scavenge and eliminate cellular debris or external pathological agents in specific brain areas. They can also support tissue maintenance and plasticity of neural circuits by supplying neurotrophic factors [139], and protect and remodel synapses [140]. Upon activation, microglia spread and start to migrate to the specific injury location, which triggers the innate immune response. Microglia bind to soluble $A \beta$ oligomers and $A \beta$ fibrils through receptors, including class A scavenger receptor, CD36, and toll like receptors (TLR types 4 and 6) [141-144], which activates microglia to begin forming proinflammatory cytokines and chemokines [143, 145] to initiate an inflammatory response. The secretions of proinflammatory cytokines and chemokines are CD36- and TLR-dependent, as deletion of these two genes in vitro decreased the generation of $A \beta$-induced cytokines [143, 145, 146] and prevented the accumulation of intracellular amyloid and activation of inflammasomes [146]. Despite initiating neuroinflammation, microglia in fact also exhibit great efficacy in suppressing amyloid deposits [147]. Specifically, blood-derived microglia were able to eliminate amyloid deposition by phagocytosis via direct binding of microglia to $A \beta$ [147]. Another study showed that the accumulation of microglia prior to $A \beta$ elimination was mediated by its chemokine receptor $C c r 2$, the depletion of which induced increased $A \beta$ deposition [148]. Additionally, $\mathrm{Tg} 2576$, a transgenic animal model of $\mathrm{AD}$, displayed high premature fatality upon $C \mathrm{cr} 2$ deficiency, which further implies that $C c r 2$-dependent microglial $A \beta$ clearance may exert neuroprotective effects in early $\mathrm{AD}$. These findings further demonstrate the bidirectional consequences of microglial activation in the brain, given its roles in $\mathrm{A} \beta$ clearance and neuroinflammation.

Given that neuroinflammation has a significant role in $\mathrm{AD}$, much effort has been devoted to researching the 
therapeutic effects of anti-neuroinflammation in AD. Indeed, several epidemiological studies indicate that longterm administration of NSAIDs can reduce the risk of developing AD [149, 150]. Preclinical studies on the use of NSAIDs in AD models have provided promising results, including reduction of $A \beta$ secretion and deposition, $\gamma$-secretase activity regulation, antiinflammatory effects, and enhance cognitive functions in rodent models [151-156]. However, the translational value to the clinic remains ambiguous, as clinical evidence substantiating the therapeutic effect of NSAIDs is still lacking [157].

Besides NSAIDs, other strategies focusing on antineuroinflammation have been studied, including peroxisome proliferator-activated receptor (PPAR)- $\gamma$ agonists and antibodies that inhibit $\mathrm{TNF} \alpha$ signaling. Interestingly, administration of a commonly prescribed diabetes drug, pioglitazone, which is also a PPAR- $\gamma$ agonist, was associated with reduced dementia risk in patients who had non-insulin-dependent diabetes mellitus [158]. The PPAR- $\gamma$ agonists were found to decrease the generation of inflammatory cytokines and amyloid deposit in AD rodent models [155, 159]. Specifically, rosiglitazone was able to rescue cognitive deficits observed in the Tg2576 mouse model, possibly through ERK pathway activation [160, 161]. Increased TNF $\alpha$, which is highly implicated in neuroinflammation and cell death processes, was consistently observed in both preclinical and clinical cases. Deletion of its receptor contributed to diverse effects including BACE1 activity suppression and restoration of cognitive abilities [162, 163], suggesting TNF $\alpha$ signaling could have a modulatory role in alleviating $\mathrm{AD}$. Indeed, inhibition of TNFa signaling by antibodies against $\mathrm{TNF} \alpha$, such as infliximab, significantly reduced $A \beta$ plaque formation and tau phosphorylation in APP/PS1 mice [164], further supporting TNFa inhibition as a viable therapeutic approach.

Although neuroinflammation is considered to be involved in $\mathrm{AD}$ pathogenesis, there are many unanswered questions: What is the exact mechanism of neuroinflammation in AD? Is neuroinflammation a factor that triggers or aggravates the course of AD? To what extent does it affect the onset or progression of AD? Further studies are needed to delineate the underlying mechanisms and crucial cellular players of neuroinflammation in $\mathrm{AD}$.

\section{Neurotrophic factors}

Neurotrophic factors play crucial roles in neuronal nourishment, survival, and regeneration. Previous evidence suggest they are also involved non-neuronal tissue survival, proliferation, differentiation, and anti- inflammation processes. Additionally, they have been detected in tissue-specific adult stem cell niches involved in tissue regeneration outside of the nervous system [165167]. There has been some research into using neurotrophic factors as a treatment for AD. Neurotrophic factors were subcutaneously injected to generate a systemic exposure in an amyotrophic lateral sclerosis clinical trial $[168,169]$. However, such an administration route was demonstrated to induce significant side effects. Indeed, one of the challenges encountered was the need to enhance the specificity of the delivery of neurotrophic factors to the targeted neurons in the brain. Researchers employed intrathecal administration of neurotrophic factors, such as brain-derived neurotrophic factor (BDNF) and ciliary neurotrophic factor (CNTF), to focus the delivery to the CNS. However, analysis of lumbar and cervical taps showed the injected neurotrophic factors failed to reach the spinal cord and brain. Dose-dependent side effects were also reported after intrathecal administration of neurotrophic factors [170, 171]. These results indicate further improvements in the delivery of these therapeutics is still needed.

Gene therapy is a novel technology that can enable controllable and predictable expression of long-term biologically active proteins with high spatial specificity [172]. Previous clinical trials used this technology to genetically modify autologous fibroblasts to express human nerve growth factor (NGF), which were delivered to the basal forebrain of AD patients. The treatment was able to improve cognition and metabolic activity in cortical areas of $\mathrm{AD}$ patients, which supports the use of neurotrophic factor as an effective therapeutic agent for AD [173]. Similarly, astrocytic glial cell-line derived neurotrophic factor (GDNF) overexpression in the hippocampus induced by recombinant lentiviral vectors was able to restore cognitive function in a $3 x \mathrm{Tg}-\mathrm{AD}$ mouse model and aged rats [174, 175]. These studies demonstrate the crucial role of neurotrophic factors in the alleviation of AD symptoms. In particular, BDNF has a prominent role in facilitating neuronal survival and differentiation, neurotransmitter release, dendritic remodeling, and axonal growth [176]. Given that BDNF is essential in mediating synaptic plasticity that serves as the cellular basis of learning and memory functions in adults, BDNF may be involved in the progression of the cognitive decline in AD [177]. Acetylcholinesterase (AChE) inhibitors are recognized as a preferred treatment option for $\mathrm{AD}$, and drugs such as donepezil and galantamine have been used in early AD. Previous studies showed that restoration of BDNF levels could be induced by these two drugs in AD patients and animal models [178-180]. This may suggest that the neuroprotective effects exerted by AChE inhibitors in $\mathrm{AD}$ may be mediated by the BDNF signaling pathway. However, 
chronic galantamine treatment ( $3 \mathrm{mg} / \mathrm{kg}$, i.p., 14 days) failed to alter hippocampal BDNF levels in mice, but this result may not applicable because of differences in the physiology between wildtype and $\mathrm{AD}$ mice. Other treatments including antidepressant, phosphodiesterase inhibitors and small-molecule BDNF mimetics can enhance BDNF levels in AD. Previous clinical studies reported Cerebrolysin, a mixture of neurotrophic factors extracted from pig, had therapeutic effects as demonstrated by a persistent enhancement after shortterm treatment in $\mathrm{AD}[181,182]$. In addition, Cerebrolysin-treated apoE-ko mice had improved behavioral impairments and alleviated neurodegeneration [183]. To date, much effort has been made to explore ways to restore $\mathrm{BNDF}$ levels in the brain of $\mathrm{AD}$ patients, but there are several challenges that need to be overcome including drug biostability, BBB permeability, optimal dose, administration time, and specificity of drug molecules in diseased neurons. Further studies are needed to optimize the treatment paradigms.

\section{Neuroplasticity and neurogenesis}

Neuroplasticity is regarded as the fundamental mechanism in learning and memory and also the brain's ability to respond to neuronal injury. Neuroplasticity is a constant process in response to neuronal activity, injury, death, and neurogenesis, as well as the regulation of structural and functional processes related to axons, synapses, and dendrites. Plasticity involves various structural processes, such as synaptic function, synaptic remodeling, synaptogenesis, neurite extension, and neurogenesis. Although the response of the central nervous system has been shown to be mediated by neuroplasticity, its effects can be limited. Given that impaired neuroplasticity is observed in $\mathrm{AD}$, stimulating neuroplasticity may show promise in alleviating symptoms in $\mathrm{AD}$ [184].

Adult hippocampal neurons possess the ability to proliferate $[185,186]$ and persistently replace neurons in the area of the dentate gyrus [186], especially during learning activities [187], which suggests that adult neurogenesis is essential for cognitive behavior. Neurogenesis has been shown to decline in hippocampal areas with age [188]. Restoring neurogenesis by replenishing neural stem cells and replacing lost neurons could be an effective approach in the development of AD treatments. Such methods may be appropriate as neurogenesis naturally occurs, and thus replacement of neurons will not be affected by the stimulation of abnormal sprouting, although evidence supporting the substitution of functions in new neurons is insufficient. The most important issue is to maintain the functions of the transplanted cells, including orchestration of topographically precise migration, directed differentiation, and synapse functionality $[184,189,190]$. Peripheral injection of multipotent cells was shown to migrate from the blood lineage, which may be an approach to replacing lost neurons in the CNS [191]. While this theory may seem promising, more studies on this treatment paradigm using appropriate animal models need to be conducted to validate its effectiveness.

Neurotrophic factors serve as a prominent mediator of neurogenesis and neuroplasticity. In particular, NGF can stimulate sprouting and outgrowth when administered after onset of the cognitive impairment [192]. The responsiveness to NGF partly depends on tropomyosin receptor kinase A (TrkA) receptor expression, and was demonstrated to underlie synaptic plasticity via modulation of acetylcholine release [193, 194]. This finding indicates that NGF dynamics may be crucial to neurological functions, given the importance of cholinergic neurons in the CNS. Indeed, NGF was shown to be a crucial regulator of neuronal morphology and function, which can maintain or promote cholinergic function in $\mathrm{AD}$ through improving the survival of degenerating neurons, improving sprouting, promoting neurotransmitter synthesis, and promoting neuron firing [195]. Application of NGF in unimpaired CNS leads to enhanced growth and sprouting of cholinergic neurons, and increased choline acetyltransferase level and choline uptake [196-198]. In adults, the need for NGF in cholinergic neuron survival is still debatable [195]. Surprisingly, increased NGF was found in the cortex and hippocampus of AD brains [199-201], which may indicate the declined capacity of NGF retrograde transport in cholinergic neurons does not meet the increased demands of cholinergic input to possibly compensate the deficits in AD.

Recently NGF treatment for 12 months in AD patients resulted in cognitive improvements and reduced $A \beta$ levels in the cerebrospinal fluid [202]. However, patients responded to such treatment paradigm exhibited signs of brain atrophy, which was indicated by enhanced phosphorylated tau [202]. Moreover, some subjects reported side effects such as back pain, suggesting lower doses of NGF or other alternative routes may be needed to optimize the treatment [203].

\section{Aß inhibition / clearance}

Currently, research on neuroprotective treatments for $\mathrm{AD}$ have focused on the amyloid hypothesis, in which abnormal metabolism of APP leads to the formation of toxic $\mathrm{A} \beta$ species and subsequent manifestation of the pathological features of $\mathrm{AD}$. Based on this hypothesis, one treatment strategy would be to administer compounds that can block the generation or increase the clearance of 
A $\beta 42$ to alleviate disease progression. Currently, $32 \%$ of agents under phase 3 trials are anti-amyloid treatments, including immunotherapy $(\mathrm{n}=6)$, BACE inhibition $(\mathrm{n}=2)$, and anti-aggregation $(n=1)$. There are currently four monoclonal antibodies against $A \beta$ in phase 3 trials: Aducanumab [204], Crenezumab [205], Gantenerumab [206], and Solanezumab [122, 207]. Such antibodies bind to specific types of $A \beta$ aggregates: Aducanumab and Gantenerumab tend to bind to $A \beta$ aggregates; Solanezumab binds to soluble $A \beta$ monomers; and Crenezumab and Bapineuzumab have high affinity for $A \beta$ oligomers [208]. Several short peptides and peptidomimetics have also been used to target $A \beta$ to prevent aggregation [209]. However, the $A \beta$ binding sites of these agents are still unclear, as they differ from monoclonal antibody binding regions mentioned above [210-212].

As novel $\mathrm{AD}$ treatments, anti-A $\beta$ immunotherapy has the potential to reduce the pathological injury and improve cognitive decline, but they still need clinical trials. Active AD immunization or vaccination can be achieved by introducing $A \beta$ peptide fragments and adjuvant to trigger an immune response, leading to the generation of antibodies against $A \beta$ and removal of the $A \beta$ plaques [213]. In a randomized placebo-controlled study, mild to moderate $\mathrm{AD}$ patients were administered anti-A $\beta$ immunotherapy for 48 weeks. After the treatment period, the intervention group did not have significantly higher disability assessment scores compared to the control group. However, after 2 years, the phase 2 trial showed the intervention group had significant amyloid plaque clearance, although some patients developed aseptic meningoencephalitis and were terminated from the trial [214]. A possible reason for this adverse reaction might be due to adjuvant-mediated $\mathrm{T}$ helper 1 cells infiltration into the CNS, leading to autoimmune neuritis. Other side effects of $A \beta$ immunotherapy can include amyloid-related imaging abnormalities (ARIA) [215]. Such side effects should be taken into account when assessing the trials.

\section{Pathways other than AB}

During the process of developing a new drug, a crucial step is to validate its therapeutic effect in animal models of the disease. The selected animal models should adequately mimic the crucial pathology of the disease. If the therapeutic effect is achieved in these animal models, then the drug might proceed to the next step of clinical trials. Current mouse models of AD have single or double mutations of FAD APP and/or PS1. Although these mouse models may display $A \beta$ plaques, other significant hallmarks of $\mathrm{AD}$ such as neurofibrillary tangles and neuronal loss are not present [216]. Therefore, drugs tested in such animal models may fail to achieve validity, complicating the translation of preclinical results to the clinical setting. Given that animal models based on the amyloid hypothesis do not fully reflect the pathophysiology of $\mathrm{AD}$, other pathologies might need to be considered. Here, we briefly highlight current advances in therapeutic agents that target other pathologies besides $\mathrm{A} \beta$ plaques.

Another well known hypothesis of AD is the Tau hypothesis, in which hyperphosphorylation of tau protein is a crucial event in AD pathology. Tau is a cytoplasmic protein that binds to tubulin and stabilizes microtubules to maintain cytoskeleton integrity under normal cellular physiology. Hyperphosphorylated tau leads to the formation of neurofibrillary tangles and neuropil threads that disrupt this integrity, making tau a possible target for new treatments [217]. Various agents have been designed to remove tau, prevent tau propagation, and reduce tau phosphorylation and/or neurofibrillary tangle formation. There are eight such agents currently undergoing phase 2 clinical trials, including AADvac1 [218], ABBV-8E12 [219], BIIB092 [220], LY3303560 [221], and Methylene blue $[122,222]$. At present, only one compound TRx0237(LMTX) that may reduce tau-mediated neuronal damage (DMT) is undergoing phase 3 clinical trials, which is still currently recruiting subjects [223].

Besides the above two hypotheses, recent evidence indicates a possible link between mitochondrial dysfunction and $\mathrm{AD}$ [224]. It is perhaps not surprising that drugs that can restore impaired mitochondrial functions in neurodegenerative disorders such as Parkinson's disease are now undergoing rapid development as treatments for AD. Drugs, such as Latrepirdine (Dimebon), which was shown to have neuroprotective properties in rescuing $A \beta$ induced mitochondrial impairment, have been developed for clinical use [225]. However, a phase 3 clinical trial found this drug did not improve the two endpoints (Alzheimer's disease Assessment Scale-cognitive Subscale and Alzheimer's disease Co-operative studyActivities of Daily Living Inventory) when compared to the placebo group [226].

Interventions based on RNA (antisense oligonucleotide or interference RNA), such as therapies for transthyretin-mediated amyloidosis, may have potential in treating neurological diseases. Oligonucleotide-based treatments that have shown initial effects in Huntington's disease could be applied to other neurodegenerative disease such as AD [227].

Other treatments that have been in phase 3 trials include an omega-3 polyunsaturated fatty acid (docosahexanoic acid; [228]) and vitamin E ( $\alpha$ tocopherol; [229]), both with and without the NMDA receptor antagonist memantine. The former was shown to have no clinical effects [230], but the latter antioxidant vitamin $\mathrm{E}$ is still controversial. The debate is still ongoing 
about the form of vitamin $\mathrm{E}$ and its combination treatments. Its efficacy and safety were assessed in the Selenium and vitamin E Cancer prevention trial (SELECT) for prostate cancer [231]. Cholesterollowering medications, such as HMG-CoA reductase inhibitors (statins) that are used to treat vascular disease, have also be considered as a treatment for AD or to reduce the risk of developing AD. However, two statins, atorvastatin [232] and simvastatin [233], showed no clinical benefit in phase 3 trials in AD patients [234]. A multitargeted molecule, GV-971, which showed preclinical improvements on amyloid plaques, neurofibrillary tangles, mitochondrial function, neuroinflammation and cholinergic function, has completed a phase 3 trial in China in 2018 [235], and a phase 1 investigation of its pharmacokinetics and safety doses is conducted as well [236]. The agent is currently under review by Chinese FDA. Overall, given the promising findings in preclinical studies, further clinical studies are warranted to substantiate its seemingly beneficial effects.

\section{Conclusion}

Numerous transgenic rodent models have been generated in the past two decades in the attempt to further the research on $\mathrm{AD}$ pathogenesis. Transgenic rodent models that display $A \beta$ plaque formation are valuable tools to address unanswered question about $\mathrm{A} \beta$ pathology in $\mathrm{AD}$. Development and optimization of such models will provide an ideal platform for studying disease progression and for screening therapeutic options. Although these rodent models fail to mimic all pathologies of human $\mathrm{AD}$, they are indispensable in medical research as they allow terminal experiments/procedures to investigate underlying molecular mechanisms. Thus, they continue to play an important role in advancing our understanding of $\mathrm{A} \beta$ pathology and in evaluating the efficacy and safety of potential medicines for $\mathrm{AD}$.

\section{Acknowledgements}

The scientific work was funded by grants from the Hong Kong Research Grant Council (RGC-ECS 27104616), and The University of Hong Kong URC Supplementary Funding (102009728) awarded to LWL.

\section{Conflicts of interest}

All authors declare no conflicts of interest.

\section{References}

[1] Esquerda-Canals G, Montoliu-Gaya L, Guell-Bosch J,
Villegas S (2017). Mouse Models of Alzheimer's Disease. J Alzheimers Dis, 57:1171-1183.

[2] Garre-Olmo J (2018). [Epidemiology of Alzheimer's disease and other dementias]. Rev Neurol, 66:377-386.

[3] Alzheimer's Association (2018). 2018 Alzheimer's disease facts and figures. Alzheimer's \& Dementia: The Journal of the Alzheimer's Association, 14(3):367-429.

[4] Palmer AM (2002). Pharmacotherapy for Alzheimer's disease: progress and prospects. Trends Pharmacol Sci, 23:426-433.

[5] Gomez-Isla T, Price JL, McKeel DW, Jr., Morris JC, Growdon JH, Hyman BT (1996). Profound loss of layer II entorhinal cortex neurons occurs in very mild Alzheimer's disease. J Neurosci, 16:4491-4500.

[6] Coleman PD, Flood DG (1987). Neuron numbers and dendritic extent in normal aging and Alzheimer's disease. Neurobiol Aging, 8:521-545.

[7] Fjell AM, Walhovd KB (2010). Structural brain changes in aging: courses, causes and cognitive consequences. Rev Neurosci, 21:187-221.

[8] Ball MJ (1977). Neuronal loss, neurofibrillary tangles and granulovacuolar degeneration in the hippocampus with ageing and dementia. A quantitative study. Acta Neuropathol, 37:111-118.

[9] Price JL, Ko AI, Wade MJ, Tsou SK, McKeel DW, Morris JC (2001). Neuron number in the entorhinal cortex and CA1 in preclinical Alzheimer disease. Arch Neurol, 58:1395-1402.

[10] Simic G, Kostovic I, Winblad B, Bogdanovic N (1997). Volume and number of neurons of the human hippocampal formation in normal aging and Alzheimer's disease. J Comp Neurol, 379:482-494.

[11] ter Laak HJ, Renkawek K, van Workum FP (1994). The olfactory bulb in Alzheimer disease: a morphologic study of neuron loss, tangles, and senile plaques in relation to olfaction. Alzheimer Dis Assoc Disord, 8:38-48.

[12] Whitehouse PJ, Price DL, Clark AW, Coyle JT, DeLong MR (1981). Alzheimer disease: evidence for selective loss of cholinergic neurons in the nucleus basalis. Ann Neurol, 10:122-126.

[13] Whitehouse PJ, Price DL, Struble RG, Clark AW, Coyle JT, Delon MR (1982). Alzheimer's disease and senile dementia: loss of neurons in the basal forebrain. Science, 215:1237-1239.

[14] Zarow C, Lyness SA, Mortimer JA, Chui HC (2003). Neuronal loss is greater in the locus coeruleus than nucleus basalis and substantia nigra in Alzheimer and Parkinson diseases. Arch Neurol, 60:337-341.

[15] Weinshenker D (2008). Functional consequences of locus coeruleus degeneration in Alzheimer's disease. Curr Alzheimer Res, 5:342-345.

[16] Meltzer CC, Smith G, DeKosky ST, Pollock BG, Mathis CA, Moore RY, et al. (1998). Serotonin in aging, late-life depression, and Alzheimer's disease: the emerging role of functional imaging. Neuropsychopharmacology, 18:407-430.

[17] Giannakopoulos P, Herrmann FR, Bussiere T, Bouras C, Kovari E, Perl DP, et al. (2003). Tangle and neuron 
numbers, but not amyloid load, predict cognitive status in Alzheimer's disease. Neurology, 60:1495-1500.

[18] Li B, Yamamori H, Tatebayashi Y, Shafit-Zagardo B, Tanimukai H, Chen S, et al. (2008). Failure of neuronal maturation in Alzheimer disease dentate gyrus. J Neuropathol Exp Neurol, 67:78-84.

[19] Ziabreva I, Perry E, Perry R, Minger SL, Ekonomou A, Przyborski S, et al. (2006). Altered neurogenesis in Alzheimer's disease. J Psychosom Res, 61:311-316.

[20] Jin K, Peel AL, Mao XO, Xie L, Cottrell BA, Henshall DC, et al. (2004). Increased hippocampal neurogenesis in Alzheimer's disease. Proc Natl Acad Sci U S A, 101:343-347.

[21] Alzheimer A, Stelzmann RA, Schnitzlein HN, Murtagh FR (1995). An English translation of Alzheimer's 1907 paper, "Uber eine eigenartige Erkankung der Hirnrinde". Clin Anat, 8:429-431.

[22] Kidd M (1963). Paired helical filaments in electron microscopy of Alzheimer's disease. Nature, 197:192193.

[23] Wisniewski HM, Narang HK, Terry RD (1976). Neurofibrillary tangles of paired helical filaments. J Neurol Sci, 27:173-181.

[24] Lee VM, Balin BJ, Otvos L, Jr., Trojanowski JQ (1991). A68: a major subunit of paired helical filaments and derivatized forms of normal Tau. Science, 251:675-678.

[25] Mesulam MM, Asuncion Moran M (1987). Cholinesterases within neurofibrillary tangles related to age and Alzheimer's disease. Ann Neurol, 22:223228.

[26] Perry G, Friedman R, Shaw G, Chau V (1987). Ubiquitin is detected in neurofibrillary tangles and senile plaque neurites of Alzheimer disease brains. Proc Natl Acad Sci U S A, 84:3033-3036.

[27] Love S, Saitoh T, Quijada S, Cole GM, Terry RD (1988). Alz-50, ubiquitin and tau immunoreactivity of neurofibrillary tangles, Pick bodies and Lewy bodies. J Neuropathol Exp Neurol, 47:393-405.

[28] Hyman BT, Van Hoesen GW, Beyreuther K, Masters CL (1989). A4 amyloid protein immunoreactivity is present in Alzheimer's disease neurofibrillary tangles. Neurosci Lett, 101:352-355.

[29] Morrison JH, Hof PR (1997). Life and death of neurons in the aging brain. Science, 278:412-419.

[30] Bierer LM, Hof PR, Purohit DP, Carlin L, Schmeidler $\mathrm{J}$, Davis KL, et al. (1995). Neocortical neurofibrillary tangles correlate with dementia severity in Alzheimer's disease. Arch Neurol, 52:81-88.

[31] Arriagada PV, Growdon JH, Hedley-Whyte ET, Hyman BT (1992). Neurofibrillary tangles but not senile plaques parallel duration and severity of Alzheimer's disease. Neurology, 42:631-639.

[32] Medeiros R, LaFerla FM (2013). Astrocytes: conductors of the Alzheimer disease neuroinflammatory symphony. Exp Neurol, 239:133138.

[33] Olabarria M, Noristani HN, Verkhratsky A, Rodriguez JJ (2010). Concomitant astroglial atrophy and astrogliosis in a triple transgenic animal model of
Alzheimer's disease. Glia, 58:831-838.

[34] Perl DP (2010). Neuropathology of Alzheimer's disease. Mt Sinai J Med, 77:32-42.

[35] Streit WJ, Mrak RE, Griffin WS (2004). Microglia and neuroinflammation: a pathological perspective. J Neuroinflammation, $1: 14$.

[36] Kang J, Lemaire HG, Unterbeck A, Salbaum JM, Masters CL, Grzeschik KH, et al. (1987). The precursor of Alzheimer's disease amyloid A4 protein resembles a cell-surface receptor. Nature, 325:733-736. Selkoe DJ, Yamazaki T, Citron M, Podlisny MB, Koo $\mathrm{EH}$, Teplow DB, et al. (1996). The role of APP processing and trafficking pathways in the formation of amyloid beta-protein. Ann N Y Acad Sci, 777:5764.

[38] Selkoe DJ (1998). The cell biology of beta-amyloid precursor protein and presenilin in Alzheimer's disease. Trends Cell Biol, 8:447-453.

[39] Selkoe DJ (2001). Alzheimer's disease: genes, proteins, and therapy. Physiol Rev, 81:741-766.

[40] Prelli F, Castano E, Glenner GG, Frangione B (1988). Differences between vascular and plaque core amyloid in Alzheimer's disease. J Neurochem, 51:648-651.

Hardy JA, Higgins GA (1992). Alzheimer's disease: the amyloid cascade hypothesis. Science, 256:184-185.

[42] Hardy J (2006). Has the amyloid cascade hypothesis for Alzheimer's disease been proved? Curr Alzheimer Res, 3:71-73.

[43] LaFerla FM, Green KN, Oddo S (2007). Intracellular amyloid-beta in Alzheimer's disease. Nat Rev Neurosci, 8:499-509.

[44] Do Carmo S, Cuello AC (2013). Modeling Alzheimer's disease in transgenic rats. Mol Neurodegener, 8:37.

[45] Dyrks T, Dyrks E, Masters CL, Beyreuther K (1993). Amyloidogenicity of rodent and human beta A4 sequences. FEBS Lett, 324:231-236.

[46] Martino Adami PV, Quijano C, Magnani N, Galeano P, Evelson P, Cassina A, et al. (2017). Synaptosomal bioenergetic defects are associated with cognitive impairment in a transgenic rat model of early Alzheimer's disease. J Cereb Blood Flow Metab, 37:69-84.

Skaper SD (2012). Alzheimer's disease and amyloid: culprit or coincidence? Int Rev Neurobiol, 102:277316.

[48] Guzman EA, Bouter Y, Richard BC, Lannfelt L, Ingelsson M, Paetau A, et al. (2014). Abundance of Abeta(5)-x like immunoreactivity in transgenic 5XFAD, APP/PS1KI and 3xTG mice, sporadic and familial Alzheimer's disease. Mol Neurodegener, 9:13. [49] Reinert J, Martens H, Huettenrauch M, Kolbow T, Lannfelt L, Ingelsson M, et al. (2014). Abeta38 in the brains of patients with sporadic and familial Alzheimer's disease and transgenic mouse models. J Alzheimers Dis, 39:871-881.

[50] Futai E, Osawa S, Cai T, Fujisawa T, Ishiura S, Tomita $\mathrm{T}$ (2016). Suppressor Mutations for Presenilin 1 Familial Alzheimer Disease Mutants Modulate gamma-Secretase Activities. J Biol Chem, 291:435- 
446.

[51] Buxbaum JD, Christensen JL, Ruefli AA, Greengard P, Loring JF (1993). Expression of APP in brains of transgenic mice containing the entire human APP gene. Biochem Biophys Res Commun, 197:639-645.

[52] Lamb BT, Sisodia SS, Lawler AM, Slunt HH, Kitt CA, Kearns WG, et al. (1993). Introduction and expression of the 400 kilobase amyloid precursor protein gene in transgenic mice [corrected]. Nat Genet, 5:22-30.

[53] Mucke L, Masliah E, Yu GQ, Mallory M, Rockenstein EM, Tatsuno G, et al. (2000). High-level neuronal expression of abeta 1-42 in wild-type human amyloid protein precursor transgenic mice: synaptotoxicity without plaque formation. J Neurosci, 20:4050-4058.

[54] Games D, Adams D, Alessandrini R, Barbour R, Berthelette P, Blackwell C, et al. (1995). Alzheimertype neuropathology in transgenic mice overexpressing V717F beta-amyloid precursor protein. Nature, 373:523-527.

[55] Hsiao K, Chapman P, Nilsen S, Eckman C, Harigaya Y, Younkin S, et al. (1996). Correlative memory deficits, Abeta elevation, and amyloid plaques in transgenic mice. Science, 274:99-102.

[56] Sturchler-Pierrat C, Abramowski D, Duke M, Wiederhold KH, Mistl C, Rothacher S, et al. (1997). Two amyloid precursor protein transgenic mouse models with Alzheimer disease-like pathology. Proc Natl Acad Sci U S A, 94:13287-13292.

[57] Kitazawa M, Medeiros R, Laferla FM (2012). Transgenic mouse models of Alzheimer disease: developing a better model as a tool for therapeutic interventions. Curr Pharm Des, 18:1131-1147.

[58] Hsiao KK, Borchelt DR, Olson K, Johannsdottir R, Kitt C, Yunis W, et al. (1995). Age-related CNS disorder and early death in transgenic $\mathrm{FVB} / \mathrm{N}$ mice overexpressing Alzheimer amyloid precursor proteins. Neuron, 15:1203-1218.

[59] Lesne S, Koh MT, Kotilinek L, Kayed R, Glabe CG, Yang A, et al. (2006). A specific amyloid-beta protein assembly in the brain impairs memory. Nature, 440:352-357.

[60] Irizarry MC, McNamara M, Fedorchak K, Hsiao K, Hyman BT (1997). APPSw transgenic mice develop age-related A beta deposits and neuropil abnormalities, but no neuronal loss in CA1. J Neuropathol Exp Neurol, 56:965-973.

[61] Spires-Jones TL, Meyer-Luehmann M, Osetek JD, Jones PB, Stern EA, Bacskai BJ, et al. (2007). Impaired spine stability underlies plaque-related spine loss in an Alzheimer's disease mouse model. Am J Pathol, 171:1304-1311.

[62] Beckmann N, Schuler A, Mueggler T, Meyer EP, Wiederhold KH, Staufenbiel M, et al. (2003). Agedependent cerebrovascular abnormalities and blood flow disturbances in APP23 mice modeling Alzheimer's disease. J Neurosci, 23:8453-8459.

[63] Mueggler T, Sturchler-Pierrat C, Baumann D, Rausch M, Staufenbiel M, Rudin M (2002). Compromised hemodynamic response in amyloid precursor protein transgenic mice. J Neurosci, 22:7218-7224.
Calhoun ME, Wiederhold KH, Abramowski D, Phinney AL, Probst A, Sturchler-Pierrat C, et al. (1998). Neuron loss in APP transgenic mice. Nature, 395:755-756.

[65] Rockenstein EM, McConlogue L, Tan H, Power M, Masliah E, Mucke L (1995). Levels and alternative splicing of amyloid beta protein precursor (APP) transcripts in brains of APP transgenic mice and humans with Alzheimer's disease. J Biol Chem, 270:28257-28267.

[66] Irizarry MC, Soriano F, McNamara M, Page KJ, Schenk D, Games D, et al. (1997). Abeta deposition is associated with neuropil changes, but not with overt neuronal loss in the human amyloid precursor protein V717F (PDAPP) transgenic mouse. J Neurosci, 17:7053-7059.

[67] Chishti MA, Yang DS, Janus C, Phinney AL, Horne P, Pearson J, et al. (2001). Early-onset amyloid deposition and cognitive deficits in transgenic mice expressing a double mutant form of amyloid precursor protein 695. J Biol Chem, 276:21562-21570.

[68] Ameen-Ali KE, Wharton SB, Simpson JE, Heath PR, Sharp P, Berwick J (2017). Review: Neuropathology and behavioural features of transgenic murine models of Alzheimer's disease. Neuropathol Appl Neurobiol, 43:553-570.

[69] Kobayashi DT, Chen KS (2005). Behavioral phenotypes of amyloid-based genetically modified mouse models of Alzheimer's disease. Genes Brain Behav, 4:173-196.

[70] Harris JA, Devidze N, Halabisky B, Lo I, Thwin MT, Yu GQ, et al. (2010). Many neuronal and behavioral impairments in transgenic mouse models of Alzheimer's disease are independent of caspase cleavage of the amyloid precursor protein. J Neurosci, 30:372-381.

[71] Bellucci A, Luccarini I, Scali C, Prosperi C, Giovannini MG, Pepeu G, et al. (2006). Cholinergic dysfunction, neuronal damage and axonal loss in TgCRND8 mice. Neurobiol Dis, 23:260-272.

[72] Chen S, Yadav SP, Surewicz WK (2010). Interaction between human prion protein and amyloid-beta (Abeta) oligomers: role OF N-terminal residues. J Biol Chem, 285:26377-26383.

[73] Tomiyama T, Matsuyama S, Iso H, Umeda T, Takuma $\mathrm{H}$, Ohnishi K, et al. (2010). A mouse model of amyloid beta oligomers: their contribution to synaptic alteration, abnormal tau phosphorylation, glial activation, and neuronal loss in vivo. J Neurosci, 30:4845-4856.

[74] McLean CA, Cherny RA, Fraser FW, Fuller SJ, Smith MJ, Beyreuther K, et al. (1999). Soluble pool of Abeta amyloid as a determinant of severity of neurodegeneration in Alzheimer's disease. Ann Neurol, 46:860-866.

[75] Naslund J, Haroutunian V, Mohs R, Davis KL, Davies $\mathrm{P}$, Greengard P, et al. (2000). Correlation between elevated levels of amyloid beta-peptide in the brain and cognitive decline. Jama, 283:1571-1577.

[76] Saito T, Matsuba Y, Mihira N, Takano J, Nilsson P, 
Itohara S, et al. (2014). Single App knock-in mouse models of Alzheimer's disease. Nat Neurosci, 17:661663.

[77] Chui DH, Tanahashi H, Ozawa K, Ikeda S, Checler F, Ueda O, et al. (1999). Transgenic mice with Alzheimer presenilin 1 mutations show accelerated neurodegeneration without amyloid plaque formation. Nat Med, 5:560-564.

[78] Rutten BP, Van der Kolk NM, Schafer S, van Zandvoort MA, Bayer TA, Steinbusch HW, et al. (2005). Age-related loss of synaptophysin immunoreactive presynaptic boutons within the hippocampus of APP751SL, PS1M146L, and APP751SL/PS1M146L transgenic mice. Am J Pathol, 167:161-173.

[79] Sadowski M, Pankiewicz J, Scholtzova H, Ji Y, Quartermain D, Jensen CH, et al. (2004). Amyloidbeta deposition is associated with decreased hippocampal glucose metabolism and spatial memory impairment in APP/PS1 mice. J Neuropathol Exp Neurol, 63:418-428.

[80] Borchelt DR, Ratovitski T, van Lare J, Lee MK, Gonzales V, Jenkins NA, et al. (1997). Accelerated amyloid deposition in the brains of transgenic mice coexpressing mutant presenilin 1 and amyloid precursor proteins. Neuron, 19:939-945.

[81] Oakley H, Cole SL, Logan S, Maus E, Shao P, Craft J, et al. (2006). Intraneuronal beta-amyloid aggregates, neurodegeneration, and neuron loss in transgenic mice with five familial Alzheimer's disease mutations: potential factors in amyloid plaque formation. J Neurosci, 26:10129-10140.

[82] Saito T, Suemoto T, Brouwers N, Sleegers K, Funamoto S, Mihira N, et al. (2011). Potent amyloidogenicity and pathogenicity of Abeta43. Nat Neurosci, 14:1023-1032.

[83] Paloneva J, Manninen T, Christman G, Hovanes K, Mandelin J, Adolfsson R, et al. (2002). Mutations in two genes encoding different subunits of a receptor signaling complex result in an identical disease phenotype. Am J Hum Genet, 71:656-662.

[84] Guerreiro RJ, Lohmann E, Bras JM, Gibbs JR, Rohrer JD, Gurunlian N, et al. (2013). Using exome sequencing to reveal mutations in TREM2 presenting as a frontotemporal dementia-like syndrome without bone involvement. JAMA Neurol, 70:78-84.

[85] Lee CYD, Daggett A, Gu X, Jiang LL, Langfelder P, Li X, et al. (2018). Elevated TREM2 Gene Dosage Reprograms Microglia Responsivity and Ameliorates Pathological Phenotypes in Alzheimer's Disease Models. Neuron, 97:1032-1048.e1035.

[86] Song WM, Joshita S, Zhou Y, Ulland TK, Gilfillan S, Colonna M (2018). Humanized TREM2 mice reveal microglia-intrinsic and -extrinsic effects of $\mathrm{R} 47 \mathrm{H}$ polymorphism. J Exp Med, 215:745-760.

[87] Oddo S, Caccamo A, Shepherd JD, Murphy MP, Golde TE, Kayed R, et al. (2003). Triple-transgenic model of Alzheimer's disease with plaques and tangles: intracellular Abeta and synaptic dysfunction. Neuron, 39:409-421
[88] Billings LM, Oddo S, Green KN, McGaugh JL, LaFerla FM (2005). Intraneuronal Abeta causes the onset of early Alzheimer's disease-related cognitive deficits in transgenic mice. Neuron, 45:675-688.

[89] Belfiore R, Rodin A, Ferreira E, Velazquez R, Branca C, Caccamo A, et al. (2019). Temporal and regional progression of Alzheimer's disease-like pathology in 3xTg-AD mice. Aging Cell, 18:e12873.

[90] Pooler AM, Polydoro M, Maury EA, Nicholls SB, Reddy SM, Wegmann S, et al. (2015). Amyloid accelerates tau propagation and toxicity in a model of early Alzheimer's disease. Acta Neuropathol Commun, $3: 14$.

[91] Pascoal TA, Mathotaarachchi S, Mohades S, Benedet AL, Chung CO, Shin M, et al. (2017). Amyloid-beta and hyperphosphorylated tau synergy drives metabolic decline in preclinical Alzheimer's disease. Mol Psychiatry, 22:306-311.

[92] Echeverria V, Ducatenzeiler A, Alhonen L, Janne J, Grant SM, Wandosell F, et al. (2004). Rat transgenic models with a phenotype of intracellular Abeta accumulation in hippocampus and cortex. J Alzheimers Dis, 6:209-219.

[93] Echeverria V, Ducatenzeiler A, Dowd E, Janne J, Grant SM, Szyf M, et al. (2004). Altered mitogenactivated protein kinase signaling, tau hyperphosphorylation and mild spatial learning dysfunction in transgenic rats expressing the betaamyloid peptide intracellularly in hippocampal and cortical neurons. Neuroscience, 129:583-592.

[94] Ruiz-Opazo N, Kosik KS, Lopez LV, Bagamasbad P, Ponce LR, Herrera VL (2004). Attenuated hippocampus-dependent learning and memory decline in transgenic TgAPPswe Fischer-344 rats. Mol Med, 10:36-44.

[95] Benedikz E, Kloskowska E, Winblad B (2009). The rat as an animal model of Alzheimer's disease. J Cell Mol Med, 13:1034-1042.

[96] Folkesson R, Malkiewicz K, Kloskowska E, Nilsson T, Popova E, Bogdanovic N, et al. (2007). A transgenic rat expressing human APP with the Swedish Alzheimer's disease mutation. Biochem Biophys Res Commun, 358:777-782.

[97] Kloskowska E, Pham TM, Nilsson T, Zhu S, Oberg J, Codita A, et al. (2010). Cognitive impairment in the Tg6590 transgenic rat model of Alzheimer's disease. J Cell Mol Med, 14:1816-1823.

[98] Johnson SA, Rogers J, Finch CE (1989). APP-695 transcript prevalence is selectively reduced during Alzheimer's disease in cortex and hippocampus but not in cerebellum. Neurobiol Aging, 10:755-760.

Clarke J, Thornell A, Corbett D, Soininen H, Hiltunen M, Jolkkonen J (2007). Overexpression of APP provides neuroprotection in the absence of functional benefit following middle cerebral artery occlusion in rats. Eur J Neurosci, 26:1845-1852.

[100] Whitehead S, Cheng G, Hachinski V, Cechetto DF (2005). Interaction between a rat model of cerebral ischemia and beta-amyloid toxicity: II. Effects of triflusal. Stroke, 36:1782-1789. 
[101] Brody DL, Holtzman DM (2006). Morris water maze search strategy analysis in PDAPP mice before and after experimental traumatic brain injury. Exp Neurol, 197:330-340.

[102] Popa-Wagner A, Schroder E, Walker LC, Kessler C (1998). beta-Amyloid precursor protein and ssamyloid peptide immunoreactivity in the rat brain after middle cerebral artery occlusion: effect of age. Stroke, 29:2196-2202.

[103] Nihashi T, Inao S, Kajita Y, Kawai T, Sugimoto T, Niwa M, et al. (2001). Expression and distribution of beta amyloid precursor protein and beta amyloid peptide in reactive astrocytes after transient middle cerebral artery occlusion. Acta Neurochir (Wien), 143:287-295.

[104] Agca C, Fritz JJ, Walker LC, Levey AI, Chan AW, Lah JJ, et al. (2008). Development of transgenic rats producing human beta-amyloid precursor protein as a model for Alzheimer's disease: transgene and endogenous APP genes are regulated tissuespecifically. BMC Neurosci, 9:28.

[105] Weishaupt N, Liu Q, Shin S, Singh R, Agca Y, Agca C, et al. (2018). APP21 transgenic rats develop agedependent cognitive impairment and microglia accumulation within white matter tracts. J Neuroinflammation, 15:241.

[106] Flood DG, Lin YG, Lang DM, Trusko SP, Hirsch JD, Savage MJ, et al. (2009). A transgenic rat model of Alzheimer's disease with extracellular Abeta deposition. Neurobiol Aging, 30:1078-1090.

[107] Liu L, Orozco IJ, Planel E, Wen Y, Bretteville A, Krishnamurthy $\mathrm{P}$, et al. (2008). A transgenic rat that develops Alzheimer's disease-like amyloid pathology, deficits in synaptic plasticity and cognitive impairment. Neurobiol Dis, 31:46-57.

[108] Zahorsky-Reeves J LG, Chu DK, Schimmel A, Ezell PC, Dang M, Couto M (2007). Maintaining longevity in a triple transgenic rat model of Alzheimer's disease. Am Assoc Lab Anim Sci, 46:124.

[109] Cohen RM, Rezai-Zadeh K, Weitz TM, Rentsendorj A, Gate D, Spivak I, et al. (2013). A transgenic Alzheimer rat with plaques, tau pathology, behavioral impairment, oligomeric abeta, and frank neuronal loss. J Neurosci, 33:6245-6256.

[110] Rorabaugh JM, Chalermpalanupap T, Botz-Zapp CA, Fu VM, Lembeck NA, Cohen RM, et al. (2017). Chemogenetic locus coeruleus activation restores reversal learning in a rat model of Alzheimer's disease. Brain, 140:3023-3038.

[111] Leon WC, Canneva F, Partridge V, Allard S, Ferretti MT, DeWilde A, et al. (2010). A novel transgenic rat model with a full Alzheimer's-like amyloid pathology displays pre-plaque intracellular amyloid-betaassociated cognitive impairment. J Alzheimers Dis, 20:113-126.

[112] Galeano P, Martino Adami PV, Do Carmo S, Blanco E, Rotondaro C, Capani F, et al. (2014). Longitudinal analysis of the behavioral phenotype in a novel transgenic rat model of early stages of Alzheimer's disease. Front Behav Neurosci, 8:321.
[113] Agca C, Klakotskaia D, Schachtman TR, Chan AW, Lah JJ, Agca Y (2016). Presenilin 1 transgene addition to amyloid precursor protein overexpressing transgenic rats increases amyloid beta 42 levels and results in loss of memory retention. BMC Neurosci, 17:46.

[114] Klakotskaia D, Agca C, Richardson RA, Stopa EG, Schachtman TR, Agca Y (2018). Memory deficiency, cerebral amyloid angiopathy, and amyloid-beta plaques in APP $+\mathrm{PS} 1$ double transgenic rat model of Alzheimer's disease. PLoS One, 13:e0195469.

[115] Gibbs RA, Weinstock GM, Metzker ML, Muzny DM, Sodergren EJ, Scherer S, et al. (2004). Genome sequence of the Brown Norway rat yields insights into mammalian evolution. Nature, 428:493-521.

[116] Jacob HJ, Kwitek AE (2002). Rat genetics: attaching physiology and pharmacology to the genome. Nat Rev Genet, 3:33-42.

[117] Lin JH (1995). Species similarities and differences in pharmacokinetics. Drug Metab Dispos, 23:1008-1021.

[118] McLean JW, Fukazawa C, Taylor JM (1983). Rat apolipoprotein E mRNA. Cloning and sequencing of double-stranded cDNA. J Biol Chem, 258:8993-9000.

[119] Rajavashisth TB, Kaptein JS, Reue KL, Lusis AJ (1985). Evolution of apolipoprotein E: mouse sequence and evidence for an 11-nucleotide ancestral unit. Proc Natl Acad Sci U S A, 82:8085-8089.

[120] Tesson L, Cozzi J, Menoret S, Remy S, Usal C, Fraichard A, et al. (2005). Transgenic modifications of the rat genome. Transgenic Res, 14:531-546.

[121] Whishaw IQ, Metz GA, Kolb B, Pellis SM (2001). Accelerated nervous system development contributes to behavioral efficiency in the laboratory mouse: a behavioral review and theoretical proposal. Dev Psychobiol, 39:151-170.

[122] Cummings J, Lee G, Ritter A, Sabbagh M, Zhong K (2019). Alzheimer's disease drug development pipeline: 2019. Alzheimers Dement (N Y), 5:272-293.

[123] Westerman MA, Cooper-Blacketer D, Mariash A, Kotilinek L, Kawarabayashi T, Younkin LH, et al. (2002). The relationship between Abeta and memory in the Tg2576 mouse model of Alzheimer's disease. J Neurosci, 22:1858-1867.

[124] Buccafusco JJ. 2009. Frontiers in Neuroscience. In Methods of Behavior Analysis in Neuroscience. J.J. Buccafusco, editor. Boca Raton (FL): CRC Press/Taylor \& Francis

Taylor \& Francis Group, LLC.

[125] Sweeney MD, Sagare AP, Zlokovic BV (2018). Bloodbrain barrier breakdown in Alzheimer disease and other neurodegenerative disorders. Nat Rev Neurol, 14:133-150.

[126] Hensley K (2010). Neuroinflammation in Alzheimer's disease: mechanisms, pathologic consequences, and potential for therapeutic manipulation. J Alzheimers Dis, 21:1-14.

[127] in t' Veld BA, Ruitenberg A, Hofman A, Launer LJ, van Duijn CM, Stijnen T, et al. (2001). Nonsteroidal antiinflammatory drugs and the risk of Alzheimer's disease. N Engl J Med, 345:1515-1521. 
[128] Sofroniew MV (2009). Molecular dissection of reactive astrogliosis and glial scar formation. Trends Neurosci, 32:638-647.

[129] Sofroniew MV, Vinters HV (2010). Astrocytes: biology and pathology. Acta Neuropathol, 119:7-35.

[130] Kummer MP, Hammerschmidt T, Martinez A, Terwel D, Eichele G, Witten A, et al. (2014). Ear2 deletion causes early memory and learning deficits in APP/PS1 mice. J Neurosci, 34:8845-8854.

[131] Olabarria M, Noristani HN, Verkhratsky A, Rodriguez JJ (2011). Age-dependent decrease in glutamine synthetase expression in the hippocampal astroglia of the triple transgenic Alzheimer's disease mouse model: mechanism for deficient glutamatergic transmission? Mol Neurodegener, 6:55.

[132] Yeh CY, Vadhwana B, Verkhratsky A, Rodriguez JJ (2011). Early astrocytic atrophy in the entorhinal cortex of a triple transgenic animal model of Alzheimer's disease. ASN Neuro, 3:271-279.

[133] Kulijewicz-Nawrot M, Verkhratsky A, Chvatal A, Sykova E, Rodriguez JJ (2012). Astrocytic cytoskeletal atrophy in the medial prefrontal cortex of a triple transgenic mouse model of Alzheimer's disease. J Anat, 221:252-262.

[134] Beauquis J, Pavia P, Pomilio C, Vinuesa A, Podlutskaya N, Galvan V, et al. (2013). Environmental enrichment prevents astroglial pathological changes in the hippocampus of APP transgenic mice, model of Alzheimer's disease. Exp Neurol, 239:28-37.

[135] Furman JL, Sama DM, Gant JC, Beckett TL, Murphy MP, Bachstetter AD, et al. (2012). Targeting astrocytes ameliorates neurologic changes in a mouse model of Alzheimer's disease. J Neurosci, 32:16129-16140.

[136] Jiang Q, Lee CY, Mandrekar S, Wilkinson B, Cramer $\mathrm{P}$, Zelcer $\mathrm{N}$, et al. (2008). ApoE promotes the proteolytic degradation of Abeta. Neuron, 58:681-693.

[137] Terwel D, Steffensen KR, Verghese PB, Kummer MP, Gustafsson JA, Holtzman DM, et al. (2011). Critical role of astroglial apolipoprotein $\mathrm{E}$ and liver $\mathrm{X}$ receptor-alpha expression for microglial Abeta phagocytosis. J Neurosci, 31:7049-7059.

[138] Wyss-Coray T, Loike JD, Brionne TC, Lu E, Anankov $\mathrm{R}$, Yan F, et al. (2003). Adult mouse astrocytes degrade amyloid-beta in vitro and in situ. Nat Med, 9:453-457.

[139] Kettenmann H, Hanisch UK, Noda M, Verkhratsky A (2011). Physiology of microglia. Physiol Rev, 91:461553.

[140] Ji K, Akgul G, Wollmuth LP, Tsirka SE (2013). Microglia actively regulate the number of functional synapses. PLoS One, 8:e56293.

[141] Bamberger ME, Harris ME, McDonald DR, Husemann J, Landreth GE (2003). A cell surface receptor complex for fibrillar beta-amyloid mediates microglial activation. J Neurosci, 23:2665-2674.

[142] Paresce DM, Ghosh RN, Maxfield FR (1996). Microglial cells internalize aggregates of the Alzheimer's disease amyloid beta-protein via a scavenger receptor. Neuron, 17:553-565.
[143] Stewart CR, Stuart LM, Wilkinson K, van Gils JM, Deng J, Halle A, et al. (2010). CD36 ligands promote sterile inflammation through assembly of a Toll-like receptor 4 and 6 heterodimer. Nat Immunol, 11:155161.

[144] Liu Y, Walter S, Stagi M, Cherny D, Letiembre M, Schulz-Schaeffer W, et al. (2005). LPS receptor (CD14): a receptor for phagocytosis of Alzheimer's amyloid peptide. Brain, 128:1778-1789.

[145] El Khoury JB, Moore KJ, Means TK, Leung J, Terada $\mathrm{K}$, Toft M, et al. (2003). CD36 mediates the innate host response to beta-amyloid. J Exp Med, 197:1657-1666.

[146] Sheedy FJ, Grebe A, Rayner KJ, Kalantari P, Ramkhelawon B, Carpenter SB, et al. (2013). CD36 coordinates NLRP3 inflammasome activation by facilitating intracellular nucleation of soluble ligands into particulate ligands in sterile inflammation. Nat Immunol, 14:812-820.

[147] Simard AR, Soulet D, Gowing G, Julien JP, Rivest S (2006). Bone marrow-derived microglia play a critical role in restricting senile plaque formation in Alzheimer's disease. Neuron, 49:489-502.

[148] El Khoury J, Toft M, Hickman SE, Means TK, Terada $\mathrm{K}$, Geula C, et al. (2007). Ccr2 deficiency impairs microglial accumulation and accelerates progression of Alzheimer-like disease. Nat Med, 13:432-438.

[149] Stewart WF, Kawas C, Corrada M, Metter EJ (1997). Risk of Alzheimer's disease and duration of NSAID use. Neurology, 48:626-632.

[150] Gasparini L, Ongini E, Wenk G (2004). Non-steroidal anti-inflammatory drugs (NSAIDs) in Alzheimer's disease: old and new mechanisms of action. J Neurochem, 91:521-536.

[151] Weggen S, Eriksen JL, Das P, Sagi SA, Wang R, Pietrzik CU, et al. (2001). A subset of NSAIDs lower amyloidogenic Abeta42 independently of cyclooxygenase activity. Nature, 414:212-216.

[152] McKee AC, Carreras I, Hossain L, Ryu H, Klein WL, Oddo S, et al. (2008). Ibuprofen reduces Abeta, hyperphosphorylated tau and memory deficits in Alzheimer mice. Brain Res, 1207:225-236.

[153] Lim GP, Yang F, Chu T, Gahtan E, Ubeda O, Beech W, et al. (2001). Ibuprofen effects on Alzheimer pathology and open field activity in APPsw transgenic mice. Neurobiol Aging, 22:983-991.

[154] Kukar T, Prescott S, Eriksen JL, Holloway V, Murphy MP, Koo EH, et al. (2007). Chronic administration of $\mathrm{R}$-flurbiprofen attenuates learning impairments in transgenic amyloid precursor protein mice. BMC Neurosci, 8:54.

[155] Heneka MT, Sastre M, Dumitrescu-Ozimek L, Hanke A, Dewachter I, Kuiperi C, et al. (2005). Acute treatment with the PPARgamma agonist pioglitazone and ibuprofen reduces glial inflammation and Abeta142 levels in APPV717I transgenic mice. Brain, 128:1442-1453.

[156] Carreras I, McKee AC, Choi JK, Aytan N, Kowall NW, Jenkins BG, et al. (2013). R-flurbiprofen improves tau, but not Ass pathology in a triple transgenic model of Alzheimer's disease. Brain Res, 1541:115-127. 
[157] Jaturapatporn D, Isaac MG, McCleery J, Tabet N (2012). Aspirin, steroidal and non-steroidal antiinflammatory drugs for the treatment of Alzheimer's disease. Cochrane Database Syst Rev:Cd006378.

[158] Heneka MT, Fink A, Doblhammer G (2015). Effect of pioglitazone medication on the incidence of dementia. Ann Neurol, 78:284-294.

[159] Hu WT, Holtzman DM, Fagan AM, Shaw LM, Perrin R, Arnold SE, et al. (2012). Plasma multianalyte profiling in mild cognitive impairment and Alzheimer disease. Neurology, 79:897-905.

[160] Jahrling JB, Hernandez CM, Denner L, Dineley KT (2014). PPARgamma recruitment to active ERK during memory consolidation is required for Alzheimer's disease-related cognitive enhancement. J Neurosci, 34:4054-4063.

[161] Denner LA, Rodriguez-Rivera J, Haidacher SJ, Jahrling JB, Carmical JR, Hernandez CM, et al. (2012). Cognitive enhancement with rosiglitazone links the hippocampal PPARgamma and ERK MAPK signaling pathways. J Neurosci, 32:16725-16735a.

[162] McCoy MK, Tansey MG (2008). TNF signaling inhibition in the CNS: implications for normal brain function and neurodegenerative disease. $\mathrm{J}$ Neuroinflammation, 5:45.

[163] He P, Zhong Z, Lindholm K, Berning L, Lee W, Lemere C, et al. (2007). Deletion of tumor necrosis factor death receptor inhibits amyloid beta generation and prevents learning and memory deficits in Alzheimer's mice. J Cell Biol, 178:829-841.

[164] Shi JQ, Shen W, Chen J, Wang BR, Zhong LL, Zhu YW, et al. (2011). Anti-TNF-alpha reduces amyloid plaques and tau phosphorylation and induces CD11cpositive dendritic-like cell in the APP/PS1 transgenic mouse brains. Brain Res, 1368:239-247.

[165] Matsuda H, Coughlin MD, Bienenstock J, Denburg JA (1988). Nerve growth factor promotes human hemopoietic colony growth and differentiation. Proc Natl Acad Sci U S A, 85:6508-6512.

[166] Meng X, Lindahl M, Hyvonen ME, Parvinen M, de Rooij DG, Hess MW, et al. (2000). Regulation of cell fate decision of undifferentiated spermatogonia by GDNF. Science, 287:1489-1493.

[167] Lavasani M, Lu A, Peng H, Cummins J, Huard J (2006). Nerve growth factor improves the muscle regeneration capacity of muscle stem cells in dystrophic muscle. Hum Gene Ther, 17:180-192.

[168] The BDNF study group (1999). A controlled trial of recombinant methionyl human BDNF in ALS: The BDNF Study Group (Phase III). Neurology, 52:14271433.

[169] Sorenson EJ, Windbank AJ, Mandrekar JN, Bamlet WR, Appel SH, Armon C, et al. (2008). Subcutaneous IGF-1 is not beneficial in 2-year ALS trial. Neurology, 71:1770-1775.

[170] Aebischer P, Schluep M, Deglon N, Joseph JM, Hirt L, Heyd B, et al. (1996). Intrathecal delivery of CNTF using encapsulated genetically modified xenogeneic cells in amyotrophic lateral sclerosis patients. Nat Med, 2:696-699.
[171] Beck M, Flachenecker P, Magnus T, Giess R, Reiners $\mathrm{K}$, Toyka KV, et al. (2005). Autonomic dysfunction in ALS: a preliminary study on the effects of intrathecal BDNF. Amyotroph Lateral Scler Other Motor Neuron Disord, 6:100-103.

[172] Herzog CD, Bishop KM, Brown L, Wilson A, Kordower JH, Bartus RT (2011). Gene transfer provides a practical means for safe, long-term, targeted delivery of biologically active neurotrophic factor proteins for neurodegenerative diseases. Drug Deliv Transl Res, 1:361-382.

[173] Tuszynski MH, Thal L, Pay M, Salmon DP, U HS, Bakay R, et al. (2005). A phase 1 clinical trial of nerve growth factor gene therapy for Alzheimer disease. Nat Med, 11:551-555.

[174] Pertusa M, Garcia-Matas S, Mammeri H, Adell A, Rodrigo T, Mallet J, et al. (2008). Expression of GDNF transgene in astrocytes improves cognitive deficits in aged rats. Neurobiol Aging, 29:1366-1379.

[175] Revilla S, Ursulet S, Alvarez-Lopez MJ, Castro-Freire M, Perpina U, Garcia-Mesa Y, et al. (2014). LentiGDNF gene therapy protects against Alzheimer's disease-like neuropathology in 3xTg-AD mice and MC65 cells. CNS Neurosci Ther, 20:961-972.

[176] Voineskos AN, Lerch JP, Felsky D, Shaikh S, Rajji TK, Miranda D, et al. (2011). The brain-derived neurotrophic factor Val66Met polymorphism and prediction of neural risk for Alzheimer disease. Arch Gen Psychiatry, 68:198-206.

[177] Sandhya VK, Raju R, Verma R, Advani J, Sharma R, Radhakrishnan A, et al. (2013). A network map of BDNF/TRKB and BDNF/p75NTR signaling system. J Cell Commun Signal, 7:301-307.

[178] Leyhe T, Stransky E, Eschweiler GW, Buchkremer G, Laske C (2008). Increase of BDNF serum concentration during donepezil treatment of patients with early Alzheimer's disease. Eur Arch Psychiatry Clin Neurosci, 258:124-128.

[179] Autio H, Matlik K, Rantamaki T, Lindemann L, Hoener MC, Chao M, et al. (2011). Acetylcholinesterase inhibitors rapidly activate Trk neurotrophin receptors in the mouse hippocampus. Neuropharmacology, 61:1291-1296.

[180] Sakr HF, Khalil KI, Hussein AM, Zaki MS, Eid RA, Alkhateeb M (2014). Effect of dehydroepiandrosterone (DHEA) on memory and brain derived neurotrophic factor (BDNF) in a rat model of vascular dementia. J Physiol Pharmacol, 65:41-53.

[181] Bae CY, Cho CY, Cho K, Hoon Oh B, Choi KG, Lee HS, et al. (2000). A double-blind, placebo-controlled, multicenter study of Cerebrolysin for Alzheimer's disease. J Am Geriatr Soc, 48:1566-1571.

[182] Ruther E, Ritter R, Apecechea M, Freytag S, Gmeinbauer R, Windisch M (2000). Sustained improvements in patients with dementia of Alzheimer's type (DAT) 6 months after termination of Cerebrolysin therapy. J Neural Transm (Vienna), 107:815-829.

[183] Masliah E, Armasolo F, Veinbergs I, Mallory M, 
Samuel W (1999). Cerebrolysin ameliorates performance deficits, and neuronal damage in apolipoprotein E-deficient mice. Pharmacol Biochem Behav, 62:239-245.

[184] Horner PJ, Gage FH (2000). Regenerating the damaged central nervous system. Nature, 407:963-970.

[185] Brewer GJ (1999). Regeneration and proliferation of embryonic and adult rat hippocampal neurons in culture. Exp Neurol, 159:237-247.

[186] Seaberg RM, van der Kooy D (2002). Adult rodent neurogenic regions: the ventricular subependyma contains neural stem cells, but the dentate gyrus contains restricted progenitors. J Neurosci, 22:17841793.

[187] Gould E, Beylin A, Tanapat P, Reeves A, Shors TJ (1999). Learning enhances adult neurogenesis in the hippocampal formation. Nat Neurosci, 2:260-265.

[188] Cameron HA, McKay RD (1999). Restoring production of hippocampal neurons in old age. Nat Neurosci, 2:894-897.

[189] Flax JD, Aurora S, Yang C, Simonin C, Wills AM, Billinghurst LL, et al. (1998). Engraftable human neural stem cells respond to developmental cues, replace neurons, and express foreign genes. Nat Biotechnol, 16:1033-1039.

[190] Zhou W, Raisman G, Zhou C (1998). Transplanted embryonic entorhinal neurons make functional synapses in adult host hippocampus. Brain Res, 788:202-206.

[191] Ono K, Takii T, Onozaki K, Ikawa M, Okabe M, Sawada M (1999). Migration of exogenous immature hematopoietic cells into adult mouse brain parenchyma under GFP-expressing bone marrow chimera. Biochem Biophys Res Commun, 262:610614.

[192] Sofroniew MV, Howe CL, Mobley WC (2001). Nerve growth factor signaling, neuroprotection, and neural repair. Annu Rev Neurosci, 24:1217-1281.

[193] Knipper M, da Penha Berzaghi M, Blochl A, Breer H, Thoenen H, Lindholm D (1994). Positive feedback between acetylcholine and the neurotrophins nerve growth factor and brain-derived neurotrophic factor in the rat hippocampus. Eur J Neurosci, 6:668-671.

[194] Holtzman DM, Kilbridge J, Li Y, Cunningham ET, Jr., Lenn NJ, Clary DO, et al. (1995). TrkA expression in the CNS: evidence for the existence of several novel NGF-responsive CNS neurons. J Neurosci, 15:15671576.

[195] Rattray M (2001). Is there nicotinic modulation of nerve growth factor? Implications for cholinergic therapies in Alzheimer's disease. Biol Psychiatry, 49:185-193.

[196] Mobley WC, Rutkowski JL, Tennekoon GI, Buchanan K, Johnston MV (1985). Choline acetyltransferase activity in striatum of neonatal rats increased by nerve growth factor. Science, 229:284-287.

[197] Higgins GA, Koh S, Chen KS, Gage FH (1989). NGF induction of NGF receptor gene expression and cholinergic neuronal hypertrophy within the basal forebrain of the adult rat. Neuron, 3:247-256.
[198] Heisenberg CP, Cooper JD, Berke J, Sofroniew MV (1994). NMDA potentiates NGF-induced sprouting of septal cholinergic fibres. Neuroreport, 5:413-416.

[199] Jette N, Cole MS, Fahnestock M (1994). NGF mRNA is not decreased in frontal cortex from Alzheimer's disease patients. Brain Res Mol Brain Res, 25:242-250. [200] Scott SA, Mufson EJ, Weingartner JA, Skau KA, Crutcher KA (1995). Nerve growth factor in Alzheimer's disease: increased levels throughout the brain coupled with declines in nucleus basalis. $\mathrm{J}$ Neurosci, 15:6213-6221.

[201] Hock C, Heese K, Muller-Spahn F, Hulette C, Rosenberg C, Otten U (1998). Decreased trkA neurotrophin receptor expression in the parietal cortex of patients with Alzheimer's disease. Neurosci Lett, 241:151-154.

[202] Ferreira D, Westman E, Eyjolfsdottir H, Almqvist P, Lind G, Linderoth B, et al. (2015). Brain changes in Alzheimer's disease patients with implanted encapsulated cells releasing nerve growth factor. J Alzheimers Dis, 43:1059-1072.

[203] Eriksdotter Jonhagen M, Nordberg A, Amberla K, Backman L, Ebendal T, Meyerson B, et al. (1998). Intracerebroventricular infusion of nerve growth factor in three patients with Alzheimer's disease. Dement Geriatr Cogn Disord, 9:246-257.

[204] NCT02484547 (2015). A Phase 3 Multicenter, Randomized, Double-Blind, Placebo-Controlled, Parallel-Group Study to Evaluate the Efficacy and Safety of Aducanumab (BIIB037) in Subjects With Early Alzheimer's Disease.

[205] NCT02670083 (2016). A Phase III, Multicenter, Randomized, Double-Blind, Placebo-Controlled, Parallel-Group, Efficacy And Safety Study of Crenezumab in Patients With Prodromal to Mild Alzheimer's Disease.

[206] NCT02051608 (2014). A Phase III, Randomized, Double-Blind, Placebo-Controlled, Parallel-Group, Multicenter, Efficacy and Safety Study of Gantenerumab in Patients With Mild Alzheimer's Disease; Part II: Open-Label Extension For Participating Patients.

[207] NCT02008357 (2014). Anti-Amyloid Treatment in Asymptomatic Alzheimer's Disease (A4 Study).

[208] Kozin SA, Barykin EP, Mitkevich VA, Makarov AA (2018). Anti-amyloid Therapy of Alzheimer's Disease: Current State and Prospects. Biochemistry (Mosc), 83:1057-1067.

[209] Du QS, Xie NZ, Huang RB (2015). Recent development of peptide drugs and advance on theory and methodology of peptide inhibitor design. Med Chem, 11:235-247.

[210] Cho PY, Joshi G, Johnson JA, Murphy RM (2014). Transthyretin-derived peptides as beta-amyloid inhibitors. ACS Chem Neurosci, 5:542-551.

[211] Parthsarathy V, McClean PL, Holscher C, Taylor M, Tinker C, Jones G, et al. (2013). A novel retro-inverso peptide inhibitor reduces amyloid deposition, oxidation and inflammation and stimulates neurogenesis in the APPswe/PS1DeltaE9 mouse 
model of Alzheimer's disease. PLoS One, 8:e54769.

[212] Wang Q, Liang G, Zhang M, Zhao J, Patel K, Yu X, et al. (2014). De novo design of self-assembled hexapeptides as beta-amyloid (Abeta) peptide inhibitors. ACS Chem Neurosci, 5:972-981.

[213] Mo JJ, Li JY, Yang Z, Liu Z, Feng JS (2017). Efficacy and safety of anti-amyloid-beta immunotherapy for Alzheimer's disease: a systematic review and network meta-analysis. Ann Clin Transl Neurol, 4:931-942.

[214] Orgogozo JM, Gilman S, Dartigues JF, Laurent B, Puel M, Kirby LC, et al. (2003). Subacute meningoencephalitis in a subset of patients with AD after Abeta42 immunization. Neurology, 61:46-54.

[215] DiFrancesco JC, Longoni M, Piazza F (2015). AntiAbeta Autoantibodies in Amyloid Related Imaging Abnormalities (ARIA): Candidate Biomarker for Immunotherapy in Alzheimer's Disease and Cerebral Amyloid Angiopathy. Front Neurol, 6:207.

[216] Radde R, Duma C, Goedert M, Jucker M (2008). The value of incomplete mouse models of Alzheimer's disease. Eur J Nucl Med Mol Imaging, 35 Suppl $1: \mathrm{S} 70-74$.

[217] Gozes I (2010). Tau pathology and future therapeutics. Curr Alzheimer Res, 7:685-696.

[218] NCT02579252 (2016). A 24 Months Randomised, Placebo-controlled, Parallel Group, Double Blinded, Multi Centre, Phase 2 Study to Assess Safety and Efficacy of AADvac1 Applied to Patients With Mild Alzheimer's Disease.

[219] NCT02880956 (2016). A Phase 2 Multiple Dose, Multicenter, Randomized, Double-Blind, PlaceboControlled Study to Evaluate the Efficacy and Safety of ABBV-8E12 in Subjects With Early Alzheimer's Disease.

[220] NCT03352557 (2018). Randomized, Double-Blind, Placebo-Controlled, Parallel-Group Study to Assess the Safety, Tolerability, and Efficacy of BIIB092 in Subjects With Mild Cognitive Impairment Due to Alzheimer's Disease or With Mild Alzheimer's Disease.

[221] NCT03518073 (2018 ). Assessment of Safety, Tolerability, and Efficacy of LY3303560 in Early Symptomatic Alzheimer's Disease.

[222] NCT02380573 (2015). Cognitive and Functional Connectivity Effects of Methylene Blue in Healthy Aging, Mild Cognitive Impairment and Alzheimer's Disease.

[223] NCT03446001 (2018). Randomized, Double-Blind, Placebo-Controlled, Three-Arm, 9-Month, Brain Imaging and Safety and Efficacy Study of TRx0237 in Subjects With Early Alzheimer's Disease.

[224] Perez Ortiz JM, Swerdlow RH (2019). Mitochondrial dysfunction in Alzheimer's disease: Role in pathogenesis and novel therapeutic opportunities. Br J Pharmacol.

[225] Sabbagh MN, Shill HA (2010). Latrepirdine, a potential novel treatment for Alzheimer's disease and Huntington's chorea. Curr Opin Investig Drugs, 11:8091.

[226] Sweetlove M (2012). Phase III CONCERT Trial of
Latrepirdine. Pharm Med, 26:113-115.

[227] van Roon-Mom WMC, Roos RAC, de Bot ST (2018). Dose-Dependent Lowering of Mutant Huntingtin Using Antisense Oligonucleotides in Huntington Disease Patients. Nucleic Acid Ther, 28:59-62.

[228] NCT00440050 (2007). A Randomized Double-Blind Placebo-Controlled Trial Of The Effects Of Docosahexaenoic Acid (DHA) In Slowing The Progression Of Alzheimer's Disease.

[229] NCT00235716 (2007). CSP \#546 - A Randomized, Clinical Trial of Vitamin $\mathrm{E}$ and Memantine in Alzheimer's Disease (TEAM-AD).

[230] Jicha GA, Markesbery WR (2010). Omega-3 fatty acids: potential role in the management of early Alzheimer's disease. Clin Interv Aging, 5:45-61.

[231] Cervantes B, Ulatowski LM (2017). Vitamin E and Alzheimer's Disease-Is It Time for Personalized Medicine? Antioxidants (Basel), 6.

[232] NCT00151502 (2002). An 80-Week, Randomized, Multi-Center, Parallel-Group, Double-Blind Study of the Efficacy and Safety of Atorvastatin 80 MG Plus an Acetylcholinesterase Inhibitor Versus an Acetylcholinesterase Inhibitor Alone in the Treatment of Mild to Moderate Alzheimer's Disease.

[233] NCT00053599 (2002). A Multi-Center, Randomized, Double-Blind, Placebo-Controlled Trial of Simvastatin to Slow the Progression of Alzheimer's Disease.

[234] McGuinness B, Passmore P (2010). Can statins prevent or help treat Alzheimer's disease? J Alzheimers Dis, 20:925-933.

[235] Xiao S, Zhang, Z., Geng, M., GV-971 Study Group (2018). Phase 3 Clinical Trial of a Novel and Multitargeted Oligosaccharide in Patients with Mildmoderate AD in China. Clinical Trials on Alzheimer's Disease.

[236] NCT03715114 (2018). A Study to Assess the Safety and Pharmacokinetics of Oral Sodium Oligomannurarate (GV-971) in Healthy Chinese Subjects.

[237] Oules B, Del Prete D, Greco B, Zhang X, Lauritzen I, Sevalle J, et al. (2012). Ryanodine receptor blockade reduces amyloid-beta load and memory impairments in Tg2576 mouse model of Alzheimer disease. J Neurosci, 32:11820-11834.

[238] Huang SM, Mouri A, Kokubo H, Nakajima R, Suemoto T, Higuchi M, et al. (2006). Neprilysinsensitive synapse-associated amyloid-beta peptide oligomers impair neuronal plasticity and cognitive function. J Biol Chem, 281:17941-17951.

[239] Van Dam D, D'Hooge R, Staufenbiel M, Van Ginneken C, Van Meir F, De Deyn PP (2003). Age-dependent cognitive decline in the APP23 model precedes amyloid deposition. Eur J Neurosci, 17:388-396.

[240] Chen G, Chen KS, Knox J, Inglis J, Bernard A, Martin SJ, et al. (2000). A learning deficit related to age and beta-amyloid plaques in a mouse model of Alzheimer's disease. Nature, 408:975-979.

[241] Escribano L, Simon AM, Perez-Mediavilla A, SalazarColocho P, Del Rio J, Frechilla D (2009). Rosiglitazone reverses memory decline and 
hippocampal glucocorticoid receptor down-regulation in an Alzheimer's disease mouse model. Biochem Biophys Res Commun, 379:406-410.

[242] Palop JJ, Jones B, Kekonius L, Chin J, Yu GQ, Raber $\mathrm{J}$, et al. (2003). Neuronal depletion of calciumdependent proteins in the dentate gyrus is tightly linked to Alzheimer's disease-related cognitive deficits. Proc Natl Acad Sci U S A, 100:9572-9577.

[243] Ambree O, Richter H, Sachser N, Lewejohann L, Dere E, de Souza Silva MA, et al. (2009). Levodopa ameliorates learning and memory deficits in a murine model of Alzheimer's disease. Neurobiol Aging, 30:1192-1204.

[244] Kosel F, Torres Munoz P, Yang JR, Wong AA, Franklin TB (2019). Age-related changes in social behaviours in the 5xFAD mouse model of Alzheimer's disease.
Behav Brain Res, 362:160-172.

[245] Ohno M, Chang L, Tseng W, Oakley H, Citron M, Klein WL, et al. (2006). Temporal memory deficits in Alzheimer's mouse models: rescue by genetic deletion of BACE1. Eur J Neurosci, 23:251-260.

[246] Hanzel CE, Pichet-Binette A, Pimentel LS, Iulita MF, Allard S, Ducatenzeiler A, et al. (2014). Neuronal driven pre-plaque inflammation in a transgenic rat model of Alzheimer's disease. Neurobiol Aging, 35:2249-2262.

[247] Heggland I, Storkaas IS, Soligard HT, KobroFlatmoen A, Witter MP (2015). Stereological estimation of neuron number and plaque load in the hippocampal region of a transgenic rat model of Alzheimer's disease. Eur J Neurosci, 41:1245-1262. 